\title{
Sürdürülebilir Kentsel Biçim Kalitesinin Değerlendirilmesi: Bursa Yıldırım İlçesi Konut Alanları Örneği*
}

*

\author{
Arzu Taylan Susan ${ }^{1}$ \\ ORCID: 0000-0001-5718-8794
}

Zeynep Erdoğan ${ }^{3}$

ORCID: 0000-0002-4881-3524

\author{
Melek Gökmeydan ${ }^{2}$ \\ ORCID: 0000-0001-5113-5405
}

\author{
Arda Tuncer 4 \\ ORCID: 0000-0002-4846-0263
}

Öz

Kentlerde daha iyi yaşam çevrelerinin üretilmesi, şehir planlama meslek alanında fiziksel çevredeki kalite standartlarına ve bunların uygulanmasına bağhlıdır. Sürdürülebilir kentsel biçim (SKB) ilkeleri ise, daha yaşanabilir kentsel çevrelerin, komşuluk ve yapı-adası ölçeğinde tasarlanmasını ve planlanmasını gündeme getirmiştir. Bu bağlamda makale, Türkiye'deki kentsel alanları SKB ilkelerine göre değerlendirmeyi ve şehir planlamanın mekân üretme pratiğine katkı yapmayı amaçlamaktadır. Akıllı büyüme ve yeni şehircilik gibi akımların doğrultusundaki LEED-ND programında kullanılan SKB ölçütlerinin uygulanabilirliği kentsel tasarım yazın ve Türkiye imar mevzuatıla irdelenmiştir. Derişiklik/yoğunluk, erişilebilirlik, karma-arazi kullanımı, yeşil alanlar, geçirgenlik ve çeşitlilik gibi SKB ölçütlerine dair ölçüm yöntemleri geliştirildikten sonra, bunlar Bursa'nın Yıldırım ilçesinde morfolojik farklılı̆̆a sahip konut alanların temsilen altı mahallede seçilen birer yapı adası ve çevresinde incelenmiştir. Incelenen yapı adaları en fazla yoğunluk/derişiklik ve karma kullanım ilkelerini karşılarken, sürdürülebilir bir yoğunluğun gerektirdiği açık-yeşil alanlar, erişilebilirlik ve geçirgenliğin dengelenmesinde sorunlar bulunmuştur. Bu dengeyi en fazla sağlayan 1980'lerde kooperatif yoluyla üretilen konut alanlarıken, kent merkeziyle iç ve dış çeperlerde yer alan eski ve yeni konut dokularında imar mevzuatından ve toplumsal süreçlerden kaynaklanan farklı sorunlara rastlanmıştır. Sonuç olarak, bu çalışma konut alanlarının sorunları ve kent içindeki konumların göz önünde bulundurarak, geliştirdiği SKB ilkeleriyle ilgili bazı standartlar ve tasarım ölçütleri ile imar mevzuatının iyileştirilmesine katkı sağlamaktadır.

Anahtar Kelimeler: Kentsel yaşam kalitesi, mekân kalitesi, sürdürülebilir kentleşme, sürdürülebilir kentsel biçim, Yıldırım/Bursa.

\footnotetext{
* Bu makale çalışması "5.Kent Araştırmaları Kongresi” nde bidiri olarak sunulmuştur.

${ }^{1}$ Dr. Öğr. Üyesi, Bursa Teknik Üniversitesi, E-mail: arzu.susan@btu.edu.tr

2 Araş.Gör., Bursa Teknik Üniversitesi, E-mail: melek.gokmeydan@btu.edu.tr

${ }^{3}$ Araş.Gör., Bursa Teknik Üniversitesi, E-mail: zeynep.erdogan@btu.edu.tr

${ }^{4}$ Araş.Gör., Bursa Teknik Üniversitesi, E-mail: arda.tuncer@btu.edu.tr
} 


\title{
Evaluation of Sustainable Urban Form Quality: The Case of Residential Areas in Yıldırım District of Bursa
}

\author{
Arzu Taylan Susan ${ }^{5}$ \\ ORCID: 0000-0001-5718-8794
}

Zeynep Erdoğan 7

ORCID: 0000-0002-4881-3524

\author{
Melek Gökmeydan 6 \\ ORCID: 0000-0001-5113-5405 \\ Arda Tuncer 8 \\ ORCID: 0000-0002-4846-0263
}

\begin{abstract}
Better living environments in cities depends on the quality standards of physical environment and their implementation through city planning. Sustainable urban form (SUF) principles propose designing and planning of livable urban environments by focusing on neighborhood and city-block. The article aimed to evaluate urban areas in Turkey through SUF principles and to contribute into place production practice of city planning. The study searched for the applicability of SUF measures in smart growth, new urbanism and LEED-ND program by discussing through urban design literature and legislation in Turkey. After developing assessment methods for compactness/density, accessibility, mixed-land use, green areas, permeability and diversity, the study evaluated their performance in building-blocks and their environment that are selected among six neighborhoods, which represent morphological differences of residential areas in Yildirm, Bursa. Although the areas met density/compactness and mixed-land use, problems occurred in balancing sustainable density through open-green areas, accessibility and permeability. Cooperative houses of 1980's satisfied this balance, while central city and inner/outer peripheries have diverse problems due to deficiencies in legislation and social processes. In conclusion, the study contributes into development legislation by proposing standards and design indicators involved with SUF principles regarding the problems of residential areas and their location within city.
\end{abstract}

Keywords: Urban quality of life, spatial quality, sustainable urbanization, sustainable urban form, Yildirm/Bursa

\footnotetext{
${ }^{5}$ Assist. Prof. Dr., Bursa Technical University, E-mail: arzu.susan@btu.edu.tr

${ }^{6}$ Res.Assist., Bursa Technical University, E-mail: melek.gokmeydan@btu.edu.tr

${ }^{7}$ Res.Assist., Bursa Technical University, E-mail: zeynep.erdogan@btu.edu.tr

${ }^{8}$ Res.Assist., Bursa Technical University, E-mail: arda.tuncer@btu.edu.tr
} 



\section{Giriş}

Yaşam kalitesi kavramı, kalkınmada sadece ekonomi odaklı olmak yerine toplumsal ilerlemenin ölçülmesine dayalı politika geliştirmeyi savunan yaklaşımlar sonucunda, 1960 'lı yıllarda sosyal göstergeler hareketiyle birlikte ortaya çıkmıştır (Bache ve Scott, 2017; Diener ve Suh, 1997). Kentsel yaşam kalitesi araştırmaları ise, geçmişten günümüze değin bireysel odaklı, sağlık merkezli ve çevre merkezli olarak farklı alanlarda gelişen yaşam kalitesi araştırmaları alanlarından ağırlıklı olarak üçüncüsünde yer almıştır (Tekeli vd., 2010). Bu araştırmalar, 1970 'lerde kentlerde artan değişimlerle birlikte kent planlamasında önemli bir yer edinmeye başlamıştır (Türksever, 2000).

Yaşam kalitesi kavramını yeniden gündeme getiren sürdürülebilir kalkınma politikaları ise, eskiye dayanan kentsel yaşam kalitesi ve mekânsal planlama ilişkisinin sürdürülebilirlik çerçevesinde kurulmasına dikkat çekerken, bu yöndeki araştırma ve tartş̧malar devam etmektedir (Marans, 2015; Oktay, 2001; Türkoğlu, 2015). Kentler ve yaşam kalitesinin sürdürülebilirlikle ilişkisinin açıklanması için pek çok kavram ve model geliştirilmiştir (Camagni vd., 1998; Newman, 1999). Ancak, planlamanın fiziki mekân oluşturma pratiği, sürdürülebilirliğin ekonomi, toplum ve çevre bileşenlerine ek olarak, mekânın morfolojik ve kent biçimsel özelliklerinin göz önüne alınmasını gerektirmektedir (Oikonomou, 2015).

Nitekim, akıllı büyüme, yeni şehircilik gibi sürdürülebilir kentleşme yaklaşımları da genelde kentin fiziki yani kent biçimsel özellikleriyle ilgilenmektedirler (Chhetri vd., 2013; Van Kamp vd., 2003). Bu yaklaşımlar yerelde mahalle/ komşuluk gelişimine odaklanırken, mekânı biçimlendiren planlama pratiğinde kullanılabilecek kentsel biçime ilişkin ilkeler, standartlar ve tasarıma dayalı yönetmelikler geliştirmektedirler (Jabareen, 2006; Walters, 2007). Bunların uzantısinda oluşturulan LEED-ND, BREEAM, CASBEE-UD ve PCRS gibi performansa dayalı sertifika programları ise, kentsel biçimin derişiklik, erişilebilirlik gibi özelliklerini ve ekolojik anlamda kentin yerleşim yeri, su ve atık su yönetimi gibi gerekliliklerini ölçerek, yereldeki sürdürülebilirliği yaygınlaştırmak hedefindedirler (Kaya ve Taylan Susan, 2020; Ylldız vd., 2016).

Bu yeni yaklaşımlar, fiziki mekân üretimindeki planlama anlayışında niceliksel ölçümleri kullanan geleneksel planlamadan, tasarıma ve performansa dayalı bir planlama anlayışına geçilmesi yönünde değişimleri de getirmektedir (Schach-Pinsly ve Capeluto, 2020). Türkiye'deki mekânsal planlama anlayışı ve süreçleri ise, kapsamlı -geleneksel planlama anlayışına dayanmakla birlikte, 
stratejik ve sürdürülebilir planlamaya doğru bir geçiş izlenmektedir. Bu nedenle, sürdürülebilir kentleşmenin sağlanması için, mekânsal planlama pratiğinde kullanılabilecek kent biçimsel kalite ölçütlerinin geliştirilmesine yakın zamanda daha çok gereksinim duyulacaktır.

$\mathrm{Bu}$ çalışmanın amacl, sürdürülebilirlik çerçevesinde kentsel mekândaki kaliteyi biçimsel olarak ölçmeyi sağlayan ölçütleri irdeleyerek, ülkemizde daha kaliteli kentsel çevrelerin üretilmesini sağlayacak bir planlama anlayışının geliştirilmesine katkıda bulunmaktır. Bu amaca ulaşmak için, araştırılan kent-biçimsel kalite ölçütlerinin değerlendirilmesi için, ülkemize özgü farklı özelliklere sahip konut çevrelerinin incelenmesi hedeflenmiştir. Sürdürülebilir kentleşme yaklaşımlarında kent biçimine ve tasarıma dayalı araçların ve yönetmeliklerin geliştirilmesinde, kentsel morfoloji ve yapı tipolojisi arasındaki ilişkilerin incelenmesi önemli bir rol oynamıştır (Walters, 2007). Bu nedenle, kentsel biçimin irdelenmesinde, farklı tipolojik özelliklere sahip konut çevrelerinde kentsel tasarım ve morfoloji açısından incelemeler yapılması amacıyla, Bursa Yıldırım ilçesi seçilmiştir.

Bu kapsamda, makalenin ilk bölümü sürdürülebilirlik doğrultusunda bir planlama yaklaşımının kentsel alanlarda fiziksel çevredeki mekân kalitesinin nasıl değerlendirilebileceğini araştırmaktadır. Makalenin araştırma yöntemi ve saha araştırması ikinci bölümde daha detaylı açıklanmıştır. Sürdürülebilir kent-biçimine (SKB) dayalı kentsel yaşam kalitesi (KYK) ilkelerinin incelendiği Yıldırım ilçesi'nde seçilen altı mahalledeki araştırma alanlarına ve bunların karşılaştırılmasına dair bulgular, çalışmanın üçüncü bölümünde yer almaktadır. Makalenin son bölümü, bulguların değerlendirilmesini ve önerileri içermektedir.

\section{Yaşam Kalitesi, Mekânsal Planlama ve Sürdürülebilirlik}

Yaşam kalitesi, dışsal koşullar (nesnel ölçütler) ve bunların tetiklediği içsel mekanizmalarla (öznel ölçütler) birlikte ölçülmektedir (Veenhoven, 2000). Nesnel ve öznel ölçütlerle, yaşamın farklı alanlarında ve ulusal, bölgesel, yerel gibi farklı coğrafi ölçeklerde ölçülebilen yaşam kalitesi araştırmaları, kentsel politikaların geliştirilmesine ve planlamaya önemli katkılar sağlamaktadır (McCrea, Stimson, ve Marans, 2011; Pacione, 2003). Kentsel düzeydeki araştırmalar genelde fiziksel ve/veya sosyal çevreye ilişkin nesnel ve/veya öznel ölçütleri kullanmalarına göre çeşitlenirken (Chen vd., 2016; Cheng vd., 2013; Marans, 2003), yerel yönetimlerin kente müdahalesine ve mekânsal planların yapım aşamasına önemli girdileri bulunmaktadır (Bölen vd., 2006; Marans, 
2003). Bunlar, kalitenin ölçülmesinde kullanılan ölçütlere, planlama anlayışına ve ölçeğine göre değişmektedir. Fiziksel mekânın oluşmasında uyulması gereken koşulları normatif standartlarla ve kanunlarla belirleyen (Keleş, 2000) ve günümüzde halen en yaygın kullanılan planlama türü olan "kapsamlı planlama" (Ersoy, 2007) ise, çevresel/dışsal veya fiziksel mekâna ilişkin kalite araştırmalarıyla yakından ilgilidir (Bölen vd., 2006).

Çevre ve ekoloji konusunda pek çok kavram ve anlayışın 70-80'li yıllardan itibaren yer aldığı geleneksel planlamayı (Ersoy, 2007), sürdürülebilirlik, yaşam kalitesi ve kentleşmeyle ilişkilendirilen yaşam alanları (life domains), yaşanabilirlik, kentsel metabolizma ve kentsel yaşam kalitesi gibi çeşitli olgu ve modeller geliştirilmiştir (Camagni vd., 1998; Newman, 1999). Bunlar arasında yer alan "yaşam alanları" (life domains) sınıflandırması, yaşam kalitesini sürdürülebilirliğin ekonomi, çevre ve toplum boyutlarıyla ilişkilendirmeyi sağlamaktadır (Chiu, 2003). İnsan hakları ise, sürdürülebilirlik ve yaşam kalitesini kentsel mekânla ilişkilendirmek için Habitat II'de (1996) önerilen "yaşanabilirlik" kavramıyla birlikte kentsel mekânla ilişkilenmiştir (Tekeli vd., 2010).

Ancak, bazı araştırmacılar, bir şehrin sürdürülebilirliğinden söz edebilmek için, planlamanın fiziksel mekân oluşturma pratiğiyle ilgili olan "morfoloji"nin sürdürülebilirliğin dördüncü bir parametresi olarak eklenmesini önermektedir (Oikonomou, 2015). Larkham ve Jones'a (1991) göre, kentsel çevrenin fiziksel özellikleri olan sokaklar, yapı adaları, parsel ve binalar gibi anahtar öğeler ile bu öğeleri şekillendiren dönüştürücü süreçler, Kropf'a göre (2017) ise, kentsel biçim, yapı ve yapılı çevrenin özellikleri kentsel morfolojinin ilgi alanındadır. Bu nedenle, bir sonraki bölümde kentsel biçim ve sürdürülebilirlik ilişkisi incelenmiştir.

\section{Kentsel Biçim ve Sürdürülebilirlik}

"Kentsel biçim" kavramı, bir şehrin fiziksel özelliklerini tanımlamak için kullanılan arazi kullanım örüntüsü, ulaşım sistemi ve kentsel tasarımla ilişkili özelliklerin bir birleşimidir (Handy, 1996). Lynch (1981), kentsel biçimi “bir şehirdeki geniş, sabit ve kahıı fiziksel nesnelerin mekânsal örüntüsü" olarak tanımlamıştır (Makvandi ve Li, 2016). Dempsey vd. (2010), kentsel biçimin öğelerini yoğunluk, konut/bina biçimi, ulaşım altyapısı, yerleşim ve arazi kullanımı olarak sınıflandırmıştır. Jones vd.'ne göre (2010), kentsel biçimin bu öğeleri sosyal, çevresel ve ekonomik yönleriyle ilişkili olarak ele alındığı takdirde, sürdürülebilir kentsel alanlar oluşturulabilecektir. 
Kentlerin sağlıklı, yaşam kalitesi yüksek ve doğa ile uyumlu çevrelerle büyümesi ve gelişmesini hedefleyen aklll büyüme, yeni şehircilik, yeşil bina hareketi, derişik kent, ekolojik kent ve sağlıklı şehirler gibi farklı sürdürülebilir kentleşme yaklaşımları da kentsel biçimle ilgilenmektedir (El Din vd., 2013; Jabareen, 2006). Bunlar arasından akıllı büyüme ve yeni şehircilik hareketleri planlama pratiğinde uygulanmak üzere, kentsel biçime ve tasarıma dayalı yönetmelikler ve yerleşmelere ilişkin yaşam standartları gibi yeni planlama araçlarıyla yaşam kalitesini belirleyen ve sürdürülebilir mekânın oluşumunu destekleyen çözüm arayışındadır (Farr, 2008; TC-ÇŞB, 2017; Walters, 2007).

$\mathrm{Bu}$ çözümlerin geliştirilmesinde, kentsel morfoloji ve yapı tipolojisi arasındaki ilişkilerin incelenmesi önemli rol oynamıştır. Örneğin, Amerika'da Duany ve Plater-Zyberk tarafından geliştirilen Akıllı Büyüme yönetmeliğinin temelinde, arazi düzenleme planlarında belirlenen bölgelerde uygulanabilecek bina ve kentsel mekân tipolojilerine işaret edilmektedir (Rezvani Kakhki vd., 2018).

Diğer taraftan, Avrupa şehirlerinin derişik olması ve toplu taşımanın yaygın kullanımı nedeniyle, Amerika ve Avustralya'daki şehirlere göre daha az enerji harcadığını tespit eden araştırmalar sonucunda bazı ilkeler elde edilmiştir (Sınmaz 2013; Walters, 2007). Mahalle/ komşuluk düzeyinde belirlenen derişiklik, yoğunluk, erişilebilirlik, çeşitlilik, geçirgenlik, karma-arazi kullanımı, (pasif) enerji kullanımı ve yeşil alanlar gibi kentsel biçim ilkeleri, yaşam çevrelerini daha sürdürülebilir kılmaktadır (El Din vd., 2013; Jabareen, 2006).

Ayrıca, yukarıda sözü edilen sürdürülebilir kentleşme akımları uzantısında yereldeki topluluk birimlerinin daha yaşanabilir olmasını hedefleyen, her yerde uygulanabilir oldukların ileri süren LEED-ND (ABD), BREEAM (İngiltere), CASBEE-UD (Japonya) ve PCRS (Abu Dhabi) gibi sertifika programları bulunmaktadır (Farr, 2008; Shach-Pinsly ve Capeluto, 2020; Yıldız vd., 2016). Bu programlar, kentin fiziksel biçimi ile ekolojik durumunun değerlendirildiği sürdürülebilir kentleşme yaklaşımlarıyla ortak ve benzer ilkeleri ve ölçütleri barındırmaktadır (Elariane, 2012; Gouda vd., 2018).

Türkiye'de ise, sürdürülebilirlik kavramı, İmar Kanunu'nda (No:3194) ilk defa 2013 yılında yapılan değişiklikle (Ek: 12/7/2013-6495/73 md.) 8. Maddede yer almıştır. İlgili Maddeye göre, kentsel asgari standartlar Bakanlıkça belirlenen esaslar doğrultusunda Çevre Düzeni Planı ile belirlenirken, uygulamaya ilişkin kararlar, yörenin koşulları, parselin bulunduğu bölgenin genel özellikleri, yapının niteliği ve ihtiyacı, erişilebilirlik, sürdürülebilirlik ve çevreye etkisi dikkate alınarak ve ölçüleri verilerek Bakanlıkça belirlenen esaslara göre uygulama imar planında yer alacaktır. 
Bu değişiklik sonrasında, 2014 yılında yürürlüğe giren Mekânsal Planlar Yapım Yönetmeliği (MPYY) sürdürülebilirlik ve yaşam kalitesi kavramlarını içermiştir. Ancak, sürdürülebilir bir kentsel gelişme için ne tür kentsel standartların gerekli olduğuna dair belirsizlikler bulunmaktadır. Belirtilen standartlar, açik yeşil alanlar gibi kentsel donatı ve hizmetleri kişi başına düşen alan hesaplarıyla sınırlı bırakırken, bu hizmetlerin yer seçimi, dağılımı ve bunlara erişimdeki nitelik gibi konular çoğu zaman gözden kaçmaktadır. Bu nedenle, Türkiye'de mekânsal planlama pratiğinde kullanılabilecek fiziksel çevreye ilişkin kalite ölçütlerinin geliştirilmesine gereksinim bulunmaktadır. $\mathrm{Bu}$ ölçütlerin, sürdürülebilir kentsel biçimle (SKB) ilişkili olması halinde ise sadece daha yaşanabilir değil ayn zamanda daha sürdürülebilir kentsel alanların gelişmesi sağlanabilir.

\section{Sürdürülebilir Kentsel Biçim Ölçütleri}

Bu bölümde, sürdürülebilir kentleşme yaklaşımlarında ve sertifika programlarında kentsel biçime dair ele alınan bazı ölçütler, ülkemiz imar mevzuatıyla karşılaştırmalı olarak incelenmektedir. İrdelenen ölçütler, mikro ölçekte yapı adalarında ölçülebilir olmasına göre derişiklik, yoğunluk, erişilebilirlik, geçirgenlik ve çeşitlilik gibi SKB ilkelerinin ölçülmesine ilişkindir.

\section{Derişiklik ve Yoğunluk}

Derişiklik, gelecekteki kentsel gelişimin mevcut kentsel yapılara bitişik olmasını ve bağlanabilmesini sağlarken (Wheeler, 2003), kentin yayılmasını engellemekte, enerji, su, malzeme, ürün ve insan taşımacılığını en aza indirgediği için sürdürülebilirliği arttırmaktadır. Derişiklik ölçülürken, LEEDND'de yoğunluk, yol kesişimlerinin sıklı̆̆ı, bağlantılar, kapalı alanların yüzdesi kullanılmaktadır. Bu çalışma yapı adası bazında ölçütlere odaklandığı için, mahalle düzeyindeki yol kesişimlerine ve dışsal bağlantılara yer verilmemiştir.

Yoğunluk, uygun arazi kullanımı işlevleriyle birlikte ele alındığında, bireysel araç kullanımını ve dolayısıyla enerji ve fosil yakıt tüketimini azaltmaktadır (Jabareen, 2013). Yoğunluk için, kentsel tasarım açısından farklı görüşler bulunmaktadır. Alexander (1977), 7000 kişilik topluluklarda yüz yüze iletişimin ve politik olarak hesap verebilirliğin olduğunu ve bu toplulukların 500 kişilik küçük komşuluklara bölünmesini savunmuştur. Lynch'in (1981) küçük komşuluk hesabı da, 100 hanehalkından yani yaklaşık 250-300 kişiden oluşmaktadır. Perry'nin komşuluk birimi, Jacobs'un (1961) küçük kasabalara 
benzer biçimde tarif ettiği şehirdeki komşuluklarıyla benzer biçimde yaklaşık 5000 - 10.000 kişiliktir (Walters, 2017).

Yeni Şehircilik hareketinin komşulukları ortalama 2500 kişinin yaşadığ 150 kişi/ha veya 8 konut/ha iken, Britanya'daki kentsel köylerde 30-50 kişi/ha yaşamaktadır (Walters, 2017). LEED-ND yoğunluk ölçümlerini arazi kullanımına göre çeşitlendirmiştir. Konut alanlarında hektar başına düşen konut birimiyle (kb), konut-dışı kullanım alanlarında Kat Alanı Kat Sayısı (KAKS) ile, karma-kullanım alanlarında ise konut yoğunluğu ve KAKS'ın ortalaması ile hesaplanmaktadır. Konut alanlarında $25-32$ kb/ha (hane başı 4 kişiden yaklaşık 120 kişi/ha) en düşük puanı (1) alırken, 156 kb/ha'ı geçen yerler (yaklaşık 624 kişi/ha) en yüksek puanı (6) almaktadır. Konut-dışı alanlarda ise, 0.75-1.0 arasında KAKS'a sahip alanlar en düşük puanı (1), 3'ün üzeri KAKS'ı olan alanlar en yüksek puanı (6) almaktadır (LEED-ND v4, 2018).

Türkiye'de, MPYY'ne göre, nüfus yoğunlukları 1/5000 Nazım İmar Planlarında gösterilmektedir. Mevcut konut alanlarındaki yoğunluklar seyrek (50 kiş/ha'dan az), düşük (51-150 kişi/ha), orta (151-300 kişi/ha), yüksek (301-600 kişi/ha) ve çok yüksek (601 kişi/ha) olmak üzere 5 grupta sınıflandırılmaktadır. Yeni gelişme alanlarında, seyrek 50 kiş/ha'dan az), düşük (51-120 kişi/ha), orta (121-250 kişi/ha), yüksek (251-400 kişi/ha) ve çok yüksek (401 kişi/ha üstui) olarak yine 5 grupta ancak daha düşük yoğunluklarda kategorize edilmiştir. TAKS ve KAKS, 1/1000 Uygulama İmar Planlarında konut ve konut dışı alanlar için belirtilmektedir. Planlı Alanlar İmar Yönetmeliği'ne (PAİY) göre, ayrık veya blok nizam olan yerlerde, uygulama imar planında açıça belirlenmemiş ise TAKS \% 40'1 geçemez. Ancak, çekme mesafeleri ile KAKS verilip Taban Alanı Kat Sayısı (TAKS) verilmeyen parsellerde, TAKS \% 60'1 geçmemek şartıyla, çekme mesafelerine göre uygulama yapılacağı belirtilmektedir (5. Madde, 6. Fikra).

\section{Erişilebilirlik}

Sürdürülebilir kentsel biçim, kent içi seyahat esnasında enerji verimli ve çevre dostu ulaşım sistemleriyle oluşturulmalı, arazi kullanımı bunlara imkân sağlamalıdır (Jabareen, 2013). Bu amaçla, kent içinde tramvay, hafif raylı, metro veya otobüs gibi entegre edilmiş toplu taşım araçlarını içeren ulaşım sistemleri geliştirilerek, kent içindeki kamusal alanlara erişilebilirlik arttırılmaktadır (Moughtin, 2003). Yürünebilir sokakların birbirine entegre edildiği sokak ağı, kamusal ve özel alanları belirleyen yapı adalarını biçimlendirmeli, yürüme, bisiklet ve araç sürme için çoklu rotalar sağlayarak güvenli bir komşuluk sağlanmalıdır (Farr, 2008). 
Erişilebilirlik için kullanılan kamusal alanlara yürünebilirlik ölçütü genelde mesafelerle belirtilmektedir. Moughtin (2003), toplam 7500 kişinin yaşadığ yaklaşık 320-400 kişi/ha yoğunluğa sahip bir komşuluk biriminde, merkezden uzaklığın 500 metre (m.) olmasını, yürünebilir bir mesafe olarak değerlendirmektedir. Bir komşulukta merkezden çepere yürüme mesafesi, Porta ve Renne'ye göre (2005) 400-800 m., Farr'a göre (2008) $450 \mathrm{~m}$. olmalıdır. LEED-ND'ye göre, konutların çoğunluğuna $400 \mathrm{~m}$. mesafede ( 5 dakika yürümeyle) en az 4 adet, 800 $\mathrm{m}$. mesafede (10 dakika yürümeyle) ise en az 7 adet farklı hizmet birimi olmalıdir. Konutlardan ilk ve orta okullara 10 dakika $(800 \mathrm{~m}$.), liselere 20 dakika (1.6 km) yürüme mesafesinde erişilmelidir (LEED-ND v4, 2018; Zuniga-Teran vd., 2016).

Ülkemizde kamusal alanlara yürüme mesafelerinden, eğitim, sağlık ile yeşil alanların hizmet etki alanındaki nüfusun erişme mesafesi olarak söz edilmektedir (MPYY, 12. Madde). Topoğrafya, yapılaşma, yoğunluk, mevcut doku, doğal ve yapay eşiklerin uygun olması halinde asgari yürüme mesafelerine uyulacaktır. Bunlar, çocuk bahçesi, oyun alanı, açık semt spor alanı, aile sağılı merkezi, kreş, anaokulu, ilkokula takriben 500 m., ortaokullara 1000 m.ve liselere $2500 \mathrm{~m}$. olarak belirtilmiştir. Dini tesislerden mescit $(150 \mathrm{~m}$.), küçük cami $(250 \mathrm{~m}$.) ve orta büyüklükteki semt camisi $(400 \mathrm{~m}$.) yaya erişim mesafesinde bulunmalıdır (MPYY, 12. Madde). Ayrıca, nüfus yoğunluğu 1000 kişi/ha ve daha az olan yerleşim bölgeleri ile dağınık kırsal alanlarda ulaşım mesafelerinin daha fazla olabileceğinden söz edilmiştir (MPYY, 8. Madde).

Ek olarak, Nazım İmar Planı'nda, park, çocuk bahçesi, oyun alanı, meydan gibi açık ve yeşil alanların mahalle ve semt ölçeğinde merkezlerle birlikte erişilebilir şekilde planlanmasına değinilmektedir (MPYY, 23. Madde). Ayrıca, 1000 $\mathrm{m}^{2}$ 'den fazla büyüklüğe sahip yapı adalarında, ihtiyaç duyulan kültürel, sosyal ve teknik altyapının, adanın merkezine en fazla 500 metre yarıçaplı alandan karşlanması zorunluluğu bulunmaktadır (İmar Kanunu 8. Madde).

Toplu taşıma istasyonlarm dan yürüme mesafesi LEED-ND'ye göre otobüsler için $400 \mathrm{~m}$.'den, hafif raylı ve diğer raylı sistemler için $800 \mathrm{~m}$.'den az olmalıdır (Gouda ve Masoumi, 2018; LEED-ND v4, 2018). Ülkemizde bu tür bir ölçüt tanımlanmamış olmakla birlikte, ulaşım sisteminin yolculukların mesafesini kısaltacak şekilde tasarlanması esastır (MPYY, Nazım İmar Planı, 23. Madde). Ayrıca, imar planlarında araç trafiğinin azaltılması, toplu taşıma ve yaya öncelikli bir ulaşım sisteminin kurgulanması esası, sürdürülebilir ulaşım ile doğrudan ilişkilidir (MPYY, 21. Madde). Bu amaçla, toplu taşım araçlarının kullanımının teşvik edilmesi için, park et - devam et sisteminin yaygınlaştırılmasına ve toplu taşım du- 
raklarının veya istasyonlarının bulunduğu etki alanında otopark alanları ayrılmasına ve birbirine entegre olmasına ilişkin imar planlarında kararlar getirilmesinden söz edilmekte ancak bu konuda uygulanacak ölçülebilir ilkelere değinilmemektedir.

LEED-ND'de, yaya dostu ulaşım ve yaya güvenliği için, yaya yollarının ve kaldırımların sürekliliği ve genişliğine puan verilmektedir. Tüm yapı adalarındaki dolaşım ağının \%90'ı sürekliliği olan yaya yollarına ayrılmalıdır (LEED-ND v4, 2018). Yaya yollarının genişliği, karma kullanım olan yerlerde $2.4-3 \mathrm{~m}$., diğer yapı adalarında ise 1.2-1.5 m. olmalı ve taşıt trafiğinden ayrllarak güvenlik sağlanmalıdır (Zuniga-Teran vd., 2016). MPYY'de bu tür ilkeler kentsel tasarım projeleri için belirlenmiştir. Alanın özelliğine göre doluluk-boşluk oranı, yapılar arası ilişkiler, taşıt ve yaya hareketleri gibi mimari ve mekân tasarımına ilişkin ayrıntılar dikkate alınmalıdır. Ayrıca sokak ve binaların tasarımında erişilebilirlikle beraber mekânların aydınlatılması, sokakların birbiriyle ilişkisi, sokak ve meydanlara güvenli erişim ortamının sağlanması esas alınmalıdır.

LEED-ND otomobil kullanımın ve otopark alanlarmın kapladığı yerlerin azaltılmasını desteklemektedir. Sokak üzerinde araç park etme alanları, yapı adasının her iki yönündeki araç yollarının en az \%70'inde yer alabilir. Sokak üzerinde olmayan araç park alanları yapılaşma alanının \%20'sini geçmemelidir. İkincil sokaklarda yol üzeri park mümkün iken, ana caddelerde yapı adası içinde park alanları yapılması tercih edilmeli, otoparkların, yaya ve araç dolaşımını engellemeyecek şekilde olması sağlanmalıdır (LEED-ND v4, 2018; Zuniga-Teran vd., 2016). Ayrıca, paylaşımlı otopark alanları, toplu araç park yerleri ve binaların altında olmayacak şekilde yer-altı otoparkları teşvik edilmektedir (LEED-ND v4, 2018). Ülkemizde otoparklara ilişkin düzenlemeler Planlı Alanlar İmar Yönetmeliği ve Otopark Yönetmeliği'ne göre yapılmakta olup, yapılan son değişiklikle her daireye değil dairenin büyüklügüne göre otopark düzenlemesi getirilmiştir. Ayrıca, parsellerin ortak kullanabileceği otopark düzenlemesi ile ada bazında ortak otopark yapılmasının önü açlmıştır.

LEED-ND'ye göre, bisiklet ve yaya yollarını, okul, iş yeri veya diğer farklı kullanımların olduğu lokasyonlara çıkan yaklaşık 5 km'lik bir ağ oluşturması gerekmektedir. Bisiklet yolları 2.5-3.5 m.'den fazla genişlikte olmamalı, bisikletler için park etme alanları oluşturulmalıdır (LEED-ND v4, 2018).

Ülkemizde, MPYY'nin Uygulama İmar Planı'yla ilgili 24. Maddesi'nde, "araç trafiğine ayrılmış şerit sayısını azaltmamak ve ilgili TSE standartlarına uymak kaydıyla, taşıt yollarının yaya, engelli ve bisiklet kullanımına ayrılmış kısımlarının genişlikleri, Nazım İmar Planı'nda değişikliğe gerek olmaksızın Uygulama İmar Planı'nda arttırılabilir" hükmü vardır. Aynı maddede Uygulama 
İmar Planları'nda yaya ve bisiklet yolları ile bisiklet park yerleri uygulama ilkeleri geliştirilmesi esastır.

Ayrıca, 3194 sayılı İmar Kanunu 16 maddesi, ile 7153 Sayılı Çevre Kanununu ve Bazı Kanunlarda Değişiklik Yapılmasına Dair Kanun ile yeni imar planlarında bisiklet yolları ve bisiklet park istasyonları bulunması zorunlu hale getirilmiştir. 29521 sayılı Şehir İçi Yollarda Bisiklet Yolları, İstasyonları ve Bisiklet Park Yerleri Tasarımına ve Yapımına Dair Yönetmelik ile bisiklet yollarının ulaşım noktaları ve yerleşim yerlerinin merkezlerini bağlayan bir ağ oluşturacak şekilde tasarlanmasına ve park etme alanlarının düzenlenmesine değinilmiştir. Ancak, bu düzenlemeler henüz yeni olduğundan, bisiklet mevcut kentleşmiş alanlarda çok yaygın bir kullanıma sahip değildir.

\section{Geçirgenlik}

Kentsel alanda sosyal etkileşimi ve canlılı̆̆ sağlayan geçirgenlik (permeability), SKB'in bir başka ilkesidir. Geçirgenlik, yapı adalarının içerisindeki özel alandan kamusal alana yani sokağa geçişlerin sağlanması ile yapı adalarından birbirlerine geçişlere izin verme olarak kavramsallaştırılmaktadır (Carmona vd., 2003; Madanipour, 2003). Jacobs'a (1961) göre, yapı adalarının küçük olması yürünebilirlik, sosyal canlılık gibi pek çok fayda sağlamaktadır. Porta ve Renne (2005), sokak bağlantılarını geçirgenlikle ilişkilendirirken, Pakzad ve Salari (2018), sokakların geçişe izin verdiği bağlantı biçimleri arasında çıkmaz sokak (cul-de-sac) ve t-kavşakların yerine dört-yol bağlantılarını önermektedir. Benzer biçimde, LEED-ND’ye (2018) göre, çıkmaz sokaklar (cul-de-sacs) puan alamamaktadır. Diğer yandan, Farr (2008), bir komşulukta sokakların yaklaşık $180 \mathrm{~m}$. aralıklarla kesişmesini önerirken, aslında tasarımda küçük blok büyüklüklerini ve yürünebilirliği tarif etmektedir. LEED-ND (2018) ise, incelenen alanların içsel bağlantıları arasındaki mesafelerin $245 \mathrm{~m}$. veya daha az olmasını önermekte, kapalı alanların (sağlık, eğitim, askeri alanlar hariç) \%10'unundan daha fazlasına giriş yapılamıorsa, hiç puan verilmemektedir.

Geçirgenlik ada büyüklü̆̆ü açısından ele alındığında, ülkemizde, imar planlarında imar adalarının çok küçük ve parçalı olmayacak şekilde imar yollarının düzenlenmesi esas alındığından, fazla parçalı olmayan yapı adası düzenlemeleri beklenebilir (MPYY, 21. Madde, 14. Fikra). Ancak, İmar Kanunu'nda ada büyüklüğüne dair alt ve üst limitler belirtilmemekle birlikte, $1000 \mathrm{~m}^{2}$ den fazla büyüklüğe sahip yapı adalarından söz edilmektedir. Geçirgenlik, bina kütle düzeni olarak ele alındığında ise, imar mevzuatımızda TAKS ve KAKS gibi araçların dışında, bina-blok düzenine ilişkin, yapı nizamı (bitişik, ayrık, blok), bina yüksekliği ve sokak genişliği oran, ön, yan ve arka 
bahçe mesafesi, yapı yaklaşma sınırı ve cephe çizgisi gibi mekânsal düzenleme araçlarına başvurulmaktadır. Ayrıca, imar planı değişikliklerinde, önerilecek kat adetlerinin tayininde bir yola karşılıklı iki bina cephesi arasındaki asgari uzaklığın sağlanması için bir formül tanımlanmıştır (MPYY, 26. Madde).

\section{Açık ve Yeşil Alanlar}

Dışsal ve içsel bağlantıların ve geçirgenliğin sağlanması konusunda, Moughtin (2003) kamusal mekânların birbirine bağlanan yaya yolları, meydanlar ve yeşil koridorlarla desteklenmesini önermektedir. Yeşillendirme, yeşil tasarım veya biophilia gibi çeşitli başlıklarda ele alınan ortak özellik, doğayı kentin kendisine içsel olarak kucaklatan ve insanın doğaya erişimini sağlayan çeşitli açı peyzaj alanlarıyla ilgilidir ve kentsel alanı daha sürdürülebilir kılmaktadır (Farr, 2008; Jabareen, 2013).

Dünya Sağlık Örgütü'ne göre, kentsel alanlarda kişi başına en az $9 \mathrm{~m}^{2}$ yeşil alan olmalıdır. Bu oran Londra'da $40 \mathrm{~m}^{2}$, Washington'da $38 \mathrm{~m}^{2}$, Edinburgh'da $29 \mathrm{~m}^{2 \prime}$ dir (Maryanti vd. 2017). LEED-ND'ye göre, en az 2 ha'lık yeşil alana erişim 300 m.'den daha az mesafede olmalıdır. Yeşil alanların büyüklüğü arttıkça, erişim mesafeleri artmaktadır. Ayrıca konutların ortak açı ve yeşil alanlarının olması, bu alanlarda ve yollar boyunca ağaçların olması sağlanmalıdır ( $\mathrm{Zu}-$ niga-Teran vd., 2016). Yeşil alan gereksinimini karşılamak üzere açık rekreasyon faaliyet alanı olarak en az yaklaşı $4000 \mathrm{~m}^{2}$, kapalı rekreasyon alanı olarak en az $2325 \mathrm{~m}^{2}$ alan olmalıdır. Bu alanlara erişim ise yaklaşık $800 \mathrm{~m}$. olarak belirlenmiştir (Gouda ve Masoumi, 2018).

Ülkemiz imar mevzuatında, kişi başına düşen açık yeşil alanların en az 10 $\mathrm{m}^{2}$ olması şartı bulunmakla birlikte, diğer sosyal ve teknik altyapı alanlarıyla bir bütün olarak, erişilebilir şekilde merkezlerle birlikte planlanmasına değinilmektedir (MPYY, 23. Madde 5. F1kra).

\section{Karma Arazi Kullanımı}

Arazi kullanımlarının homojenleşmesi ve düşük yoğunluklu konutların geniş arazilere yayılması sonucunda araca bağımlı yaşamların yaygınlaşması yüzünden, çevreye verilen olumsuz etkiler artmaktadır (Nedovic-Budic vd., 2016). Buna karşın, ticaret, sanayi ve ulaşım gibi işlevsel arazi kullanımlarındaki çeşitliliğe işaret eden karma arazi kullanımı, işyerleri, dükkânlar ve boş zaman faaliyetleri arasındaki mesafeleri azaltarak, yürüme ve bisiklet kullanımını teşvik etmekte, hava kalitesini iyileştirmekte ve şehir estetiğini geliştirmektedir (Jabareen, 2013). Ancak, yüksek trafik hacmi, gürültü ve hava kir- 
liliği, yanıcı patlayıcı olmaları işlevlerin varlığı gibi sorunlar nedeniyle, kirletici ve tehlikeli sanayi ve üretim alanlarının konut alanları ile iç-içe olmasından sakınılmalıdır (Moughtin, 2003).

LEED-ND'ye göre, otomobil kullanımını azaltmak ve yürümeyi teşvik etmek için, konutlara $400 \mathrm{~m}$. yürüme mesafesinde günlük ihtiyaçların karşılanacağı çeşitli kullanımlar olmalıdır. Bunlar 4-7 adet kullanımdan (1), 20'nin üstü kullanıma (4) doğru artarak puan almaktadır (LEED-ND v4, 2018).

Ülkemiz imar mevzuatı, "Ticaret+Konut", "Ticaret+Turizm+Konut" ve “Turizm+Ticaret” gibi karma arazi kullanımını mümkün kılmaktadır. Bu karma kullanım alanlarında konut kullanımına yer verilmesi halinde konut kullanım oranlarını belirtilmesi ve gerektirdikleri oranda sosyal ve teknik altyapı alanlarının ayrılması zorunludur. İmar planlarında konutun yer aldığı karma kullanımlarda konut kullanım oranının belirtilmediği hallerde en fazla \% 30 konut yapılabilir (MPYY, 21. Madde, 10. Bendi). Ayrıca, Nazım İmar Planları'nda karma kullanım olarak belirlenen fonksiyonların, Uygulama İmar Planları'nda ayrıştırılması gerekmektedir (MPYY, 24. Madde, 9. Fıkra). Bunların dışında, gürültü ve kirlilik oluşturmayan ve imalâthane niteliğinde olmayan, gayrisshhi özellik taşımayan, halkın günlük ihtiyaçlarını karşılamaya yönelik dükkân, kuaför, terzi, eczane, anaokulu ve kreş ile gelişme alanları hariç; Sağlık Bakanlığınca aranan şartlar sağlanmak şartıyla bazı kullanımlara izin verilmiştir. Bu kullanımlar, otopark alanları ihtiyaa karşılayacak şekilde düzenlenmelidir (PAİY, 19. Madde, F F1krası).

\section{Çeşitlilik}

Farklı konut tipleri, bina yoğunlukları ve peyzaj gibi fiziksel çevre özellikleriyle birlikte, hanehalkı büyüklüğü, yaş grubu, kültürel özellikler ve gelir düzeyi gibi değişik sosyo-ekonomik özellikteki insanların bir arada olması yani çeşitlilik sağlandığında, yaşanılan çevrede canlılık ve hareket artmaktadır (Wheeler, 2003). LEED-ND, farklı konut tiplerine, konut yapılarının 2-3 odalı olarak çeşitlenmesine (Zuniga-Teran vd., 2016) ve farklı gelir gruplarına sahip topluluklara yüksek puan vermektedir. Simpson-çeşitlilik endeksiyle, rastgele seçilen iki konut biriminin farklı gelir gruplarına hitap edip etmediği hesaplanmaktadır (LEED-ND v4, 2018). Ülkemizde çeşitlilik konusunun yönlendirici nitelikteki kentsel tasarım rehberleri kapsamında ele alınması öngörülmektedir (MPYY, 30.Madde, 7. Fıkra). Bakanlıkça bu rehberlerin hazırlanmasında yol gösterici olması adına hazırlanan 2016 tarihli Kentsel Tasarım Rehberleri adlı yayında, "Farklılık ve Çeşitlilik" başlığı (1) karma kullanım, (2) kullanım, bina formu ve kullanıcı çeşitliliği, (3) arazi kullanımı ve işlevsel çeşitlilik, (4) sosyal örüntü içinde 
çeşitlilik ve (5) sahiplilik için farklı seçim olanakları şeklinde detaylandırılmış$\operatorname{trr}($ ÇŞB, 2016).

\section{Yöntem}

Bu çalışma kentlerde fiziksel-yapılı çevredeki kaliteyi, sürdürülebilir kentsel biçimle ilgili geliştirilen ilkeler doğrultusunda ölçmektedir. Bazı araştırmacilar kentsel yapı adalarının, sürdürülebilirliğin sosyal, ekonomik ve çevreyle ilgili tüm bileşenlerini kentlerde analiz etmek ve uygulamak için en uygun ölçek olduğunu ileri sürülmüştür (Oikonomou, 2015; Pakzad ve Salari, 2018). Bu doğrultuda, farklı özelliklere sahip ve ülkemize özgü kentsel konut alanlarına yönelik morfolojik incelemelerin yapılması için kentsel yapı adası ölçeği seçilmiştir. Araştırma alanları, fiziksel çevre açısından çeşitlilik sunması nedeniyle Bursa ili Yıldırım ilçesi konut alanları arasından seçilmiştir. Morfolojik açıdan uyum gösteren bölgelerin belirlenmesinin ardından, bu bölgelerin her birinden tipolojik özellikler gösteren yapı adalarının fiziksel nitelikleri, bu çalışmada geliştirilen Sürdürülebilir Kentsel Biçim (SKB) kalite ölçütleriyle değerlendirilmiştir.

\section{Kullanılan SKB Kalite Ölçütleri}

Çalışmada, SKB'nin ölçülmesine dair ölçütlerin geliştirilmesinde, kentsel tasarım alanındaki tartışmaların yanı sıra akıllı büyüme, yeni şehircilik, ekolojik ve derişik kentler gibi kentleşme yaklaşımları ile fiziksel çevreyi değerlendiren sertifika programlarından özellikle LEED-ND’nin kullandığı kentsel yapılı çevreye ilişkin ölçütler ve ülkemiz imar mevzuatından faydalanılmıştır. Kentsel biçimin ölçülmesinde pek çok ölçüt bulunmakla birlikte, bu çalışmanın yapı adası bazında olması nedeniyle derişiklik - yoğunluk, erişilebilirlik, geçirgenlik, karmaarazi kullanımı, yeşil alanlar ve çeşitlilik gibi SKB ilkelerine dair belirli ölçütlere yer verilmiştir. Ölçütlerin her biri için 1 ile 5 arasında puanlamayı sağlayan bir performans ölçüm sistemi geliştirilmiştir. Bazı ölçütlerde, kabul edilemez durumlar için 0 puan kullanılmıştır. Bu sınfflandırma yöntemiyle, niceliksel olmayan -Var, Yok gibi- niteliksel ölçütlerin hesaplanabilir olması sağlanmıştır. Tüm ölçütlerin ağırlık verilmeden bir araya getirilerek, ortalama puanlarının alınmasıyla SKB değerleri, yüzdelerinin alınmasıyla ölçüt karşılama oranları elde edilmiştir. Kullanılan her bir ölçütün hesaplama yöntemleri aşağıda açıklanmıştır.

\section{Derişiklik ve Yoğunluk}

Derişikliğin ölçümünde, daha çok yoğunlukla ilgili ölçütlere yer verilmiştir (Tablo 1). Yoğunluk, LEED-ND'nin mevcut konut alanlarındaki yoğunluk, konut ve karma kullanım olan yerleri bir arada değerlendirdiği yöntem esas 
alınarak ve ülkemiz mevzuatıyla uyumlu olarak MPYY'deki mevcut konut alanları için nüfus yoğunluğu, TAKS ve KAKS' in 5'li ölçekte puanlanmasıyla elde edilen değerin ortalamasıyla ölçülmüştür. İncelenen sertifika programına benzer biçimde, en yoğun alanlara en yüksek puan verilmiştir. KAKS hesaplaması yapılırken, seçilen tüm alanlardaki KAKS değerlerine göre, bir sınıflama yapılmış ve 5 grup elde edilerek, en yüksek KAKS değeri en yüksek puanı almıştır. LEED-ND'den farklı olarak, bina-kütle düzeni açısından yaşanabilir mekânlar oluşturmayı sağlayan TAKS değeri de kullanılmıştır. PAIIY (5. Madde) göz önüne alınarak, TAKS değerleri puanlanırken, küçükten büyüğe bir sıralama ile elde edilen 5 gruptan, \%60'in üzerindeki TAKS değerleri düşük puan alırken, $\% 60$ 'ın altındakilerin daha yüksek puan alması sağlanmıştır.

Tablo 1. Çalışmada Kullanılan Derişiklik-Yoğunluk Ölçütleri

\begin{tabular}{|c|c|c|}
\hline Alt-Ölçütler & Değerlendirme & Puan \\
\hline$\checkmark$ Brüt Nüfus & $\checkmark$ NY $\leq 50$ kişi/ha (Seyrek) & 1 \\
\hline Yoğunluğu (NY) & $\checkmark 51<$ NY < 150 kişi/ha (Düşük) & 2 \\
\hline \multirow[t]{3}{*}{ kişi /hektar) } & $\checkmark 151<$ NY < 300 kişi/ha (Orta) & 3 \\
\hline & $\checkmark$ 301< NY < 600 kişi/ha (Yüksek) & 4 \\
\hline & $\checkmark 601 \leq \mathrm{NY} \quad$ (Çok Yüksek) & 5 \\
\hline \multirow[t]{5}{*}{$\checkmark$ KAKS } & $\checkmark 0.10<\mathrm{KAKS}<0.10-0.50$ & 1 \\
\hline & $\checkmark 0.50<\mathrm{KAKS}<0.50-1.00$ & 2 \\
\hline & $\checkmark 1.00<\mathrm{KAKS}<1.00-1.50$ & 3 \\
\hline & $\checkmark 1.50<\mathrm{KAKS}<1.50-1.70$ & 4 \\
\hline & $\checkmark 1.80 \leq \mathrm{KAKS}$ & 5 \\
\hline \multirow{5}{*}{$\checkmark$ TAKS } & $\checkmark 0.80 \leq \mathrm{TAKS}<0.90$ & 1 \\
\hline & $\checkmark 0.70<\mathrm{TAKS}<0.80$ & 2 \\
\hline & $\checkmark 0.60<$ TAKS $<0.70$ & 3 \\
\hline & $\checkmark 0.40<$ TAKS $<0.60$ & 4 \\
\hline & $\checkmark$ TAKS $\leq 0.40$ & 5 \\
\hline
\end{tabular}

Kaynak: Değerlendirme ölçütleri yazarlar tarafından oluşturulmuştur.

\section{Erişilebilirlik}

Yaya erişimi, kamusal alanlara yürünebilirlik, toplu taşıma duraklarına erişim mesafesi ve yaya dostu ulaşım başlıklarında değerlendirilmiştir.

Yürünebilirliğin yani kamusal alanlara erişimin ölçülmesinde, ülkemiz imar mevzuatına uygun mesafeler göz önünde bulundurularak, inceleme alanındaki 
günlük ihtiyaçların karşılanabileceği ticaret alanlarına mesafeler dikkate alınmıştır (Tablo 2). Yaya olarak erişimin $500 \mathrm{~m}$. ve daha az olması durumunda en fazla puan (5), 500-1000 m. arasındaki mesafelerde orta puan (3), 1000-2500 m. mesafelerde en düşük puan (1) , 2500 m.'den fazla olan yerlere 0 puan verilmiştir.

Toplu taşıma duraklarma erişim mesafesinde sertifika programlarının kullandığına benzer bir ölçüt geliştirilmiştir. Toplu taşıma duraklarına erişim mesafesi 1000 m.'den az olanlar en düşük puanı alırken (1), 100 m.'den az olanlar en yüksek değeri almıştır.

Yaya dostu ulaşım ölçütü için, kaldırımlarda, yaya-taşıt ayrımının hiç olmadığı durumlara en az puan (0) verilmiştir. Kaldırımların olduğu ancak sürekli olmadığı, aydınlatma elemanları, ağaç, araç parkı gibi nedenlerle kesintiye uğradığı ve bir kişiden fazla kişinin yan yana yürüyemediği yerler için orta değerde puan (3) verilmiştir. Yaya ve taşıt ayrımının belirgin oluğu, kaldırımların sürekli ve yaya yürüyüşü için güvenli olduğu genişlikteki yerler (2.5-3.5 m.) en yüksek olan puanla (5) değerlendirilmiştir.

Otomobillerin park alanlarına dair geliştirilen ölçüt, alanda yapılan gözlemlere göre araç park yerinin hiç olmadığı (0), sokak üzerinde veya yakınlarda park etme alanı olup yaya ve otomobil geçişinin engellendiği (1) ve engellenmediği (3) durumlara ve yapı adası içinde park etme alanı olmasına (5) göre puanlanmıştır. Bisiklet kullanımı ile ilgili ölçüt, alanda yapılan gözlemlere göre, bisiklet ağı ve bisiklet kullanımı açısından incelenmiştir. Bisiklet yolunun olmadığı yerler en düşük puanı alırken (0), yapı adası ve çevresinde bisiklet alanı ve park etme alanı olanlara orta derecede puan (3), yapı adası ve çevresinde yaya alanları ile entegre ve sürekliliği olan bisiklet yol ağı ve bisiklet park yeri olan alanlara en yüksek puan (5) verilmiştir.

\section{Geçirgenlik}

Geçirgenliği ölçmek için yapı adası uzunluğu, konutlara erişim ve kütle-açık alan düzeni olarak üç kriter geliştirilmiştir (Tablo 3). Yapı adası uzunluğu 200 m.'den az olan yerler en yüksek puanı (5) alırken, $200 \mathrm{~m}$. ve $400 \mathrm{~m}$. arasındaki yapı adası uzunluğu olanlar orta (3), 400 m.'den uzun yapı adaları düşük (1) puan almıştır. Çıkmaz sokakların olduğu yapı adaları puan alamamıştır. Konutlara erişim ölçütünde, yapı adalarına girişlerin ve çıkışların duvar, çit gibi engellerle kısıtlanma durumu değerlendirilmiştir. Bu tip engellerin olduğu giriş ve ç1kışları aşırı kontrollü yapı adaları en düşük puanı (1) alırken, duvar gibi engeller olmasına rağmen, birden fazla giriş çkışların olduğu yarı-kontrollü yapı adaları 
orta derece (3) puanla, giriş çıkışların kısıtlanmadığı yapı adaları ise en yüksek puanla (5) değerlendirilmiştir.

Tablo 2. Çalışmada Kullanılan Erişilebilirlik Ölçütleri

\begin{tabular}{|c|c|c|}
\hline Alt-Ölçütler & Değerlendirme & Puan \\
\hline Yaya Erişimi & & \\
\hline $\begin{array}{l}\quad \checkmark \text { Yürünebilirlik } \\
\text { (Kamusal Alanlara } \\
\text { Yaya Erişimi) }\end{array}$ & $\begin{array}{cc}\checkmark & 2501 \mathrm{~m} .<\text { Yaya erişimi } \\
\checkmark & 1001 \mathrm{~m} .<\text { Yaya erişimi } \leq 2500 \mathrm{~m} . \\
\checkmark & 501 \mathrm{~m} .<\text { Yaya erişimi } \leq 1000 \mathrm{~m} . \\
\checkmark & \text { Yaya erişimi } \leq 500 \mathrm{~m} .\end{array}$ & $\begin{array}{l}0 \\
1 \\
3 \\
5\end{array}$ \\
\hline $\begin{array}{l}\checkmark \text { Toplu Taşıma } \\
\text { Duraklarına Erişim }\end{array}$ & $\begin{array}{cc}\checkmark & 1000 \mathrm{~m}<\text { Durak mesafesi } \\
\checkmark & 751 \mathrm{~m}<\text { Durak mesafesi } \leq 1000 \mathrm{~m} \\
\checkmark & 501 \mathrm{~m}<\text { Durak mesafesi } \leq 750 \mathrm{~m} \\
\checkmark & 101 \mathrm{~m}<\text { Durak mesafesi } \leq 500 \mathrm{~m} \\
\checkmark & \text { Durak mesafesi } \leq 100 \mathrm{~m}\end{array}$ & $\begin{array}{l}1 \\
2 \\
3 \\
4 \\
5\end{array}$ \\
\hline $\begin{array}{l}\checkmark \text { Yaya Dostu } \\
\text { Ulaşım }\end{array}$ & $\begin{array}{l}\checkmark \text { Yaya ile taşıt yolu ayrımı yok } \\
\checkmark \text { Yaya taşıt yol ayrımı var ama } \\
\text { düzensiz } \\
\checkmark \text { Yaya taşıt yol ayrımı belirgin }\end{array}$ & $\begin{array}{l}0 \\
3 \\
5\end{array}$ \\
\hline
\end{tabular}

Otomobil

\begin{tabular}{lll}
\hline & $\checkmark$ Araç park yeri hiç yok & 0 \\
& $\checkmark$ Sokak üzerinde/Yakınlarda park & 1 \\
& $\begin{array}{l}\checkmark \text { Sokak üzerinde/yakınlarda park etme } \\
\text { etme alanı var ama yaya ve otomobile engel } \\
\text { alanı var; yaya ve otomobil geçişini } \\
\text { engellemiyor. } \\
\checkmark \text { Yapı adası içinde park etme alanı var. }\end{array}$ & 3 \\
\hline
\end{tabular}

Bisiklet Kullanımı ve Ağı

Güvenli /

Entegre Bisiklet Yolları

$\begin{array}{ll}\checkmark \text { Yok } & 0 \\ \checkmark \text { Yapı adası içerisinde bisiklet kullanım } & 3\end{array}$
alanı ve park yeri var.

$\checkmark$ Yapı adası içerisinde ve çevresinde 5 yaya alanları ile entegre, sürekliliği olan güvenli bisiklet yol ağı ve bisiklet park yeri var.

Kaynak: Değerlendirme ölçütleri yazarlar tarafından oluşturulmuştur. 
Geçirgenlik için son ölçüt olan kütle ve açık alan düzeninde, yapı adası içerisinde binaların yerleşimi ile açık alanların düzeni irdelenmiştir. Bu kriterin değerlendirmesinde, bina yerleşimlerinin ayrık, bitişik ve blok nizam olarak değişmesi gözetilmiştir. Bitişik nizam yapıların olduğu alanlarda yapıların yapı adasını neredeyse tamamen kapladığı, ön-arka-yan bahçe mesafelerinin olmadığı ve binalar arasında neredeyse hiç boşluk olmayan yapı adaları hiç (0) puan almamıştır. Ayrik ve bitişik nizamda ön-arka-yan bahçe mesafelerinden en az birinin sağlandığı durumlara yüksek puan (5) verilmiştir. Blok nizam yapıların olduğu alanlarda ise, ortak kullanım alanlarında yayalar için güvenli ve yeşil alanların olmaması halinde hiç puan verilmezken (0), bunların olduğu yerlere yüksek puan (5) verilmiştir (Tablo 3).

Tablo 3. Çalışmada Kullanılan Geçirgenlik Ölçütleri

\begin{tabular}{|c|c|c|}
\hline Alt-Ölçütler & Değerlendirme & Puan \\
\hline $\begin{array}{l}\quad \text { Yapı Adası } \\
\text { Uzunluğu } \\
\text { (YAU) }\end{array}$ & $\begin{array}{ll} & \text { Ç1kmaz sokaklar } \\
& 400 \mathrm{~m} .<\mathrm{YAU} \\
\vee & 200 \mathrm{~m} .<\mathrm{YAU}<400 \mathrm{~m} \\
\vee & 200 \mathrm{~m} .<\mathrm{YAU}<100 \mathrm{~m} .\end{array}$ & $\begin{array}{l}0 \\
1 \\
3 \\
5\end{array}$ \\
\hline $\begin{array}{l}\qquad \text { Konutlara } \\
\text { Erişim- (duvar-sınır- } \\
\text { açı/kapalı) }\end{array}$ & $\begin{array}{l}\checkmark \text { Yapı/Yapı adası tamamen (duvar, çit, tel } \\
\text { örgü vb. ögelerle) kapatılmış --giriş aşırı kontrollü } \\
\checkmark \text { Yapılar/Yapı adası kısmen kısıtlanmış - } \\
\text { her yapıya ait girişler mevcut veya uzun mesafe } \\
\text { duvarlar bulunmuyor } \\
\checkmark \text { Yapılar/Yapı adaları kısıtlanmamış. } \\
\text { Sokağa geçişler bırakılmış }\end{array}$ & 3 \\
\hline $\begin{array}{l}\qquad \text { Kütle ve Açık } \\
\text { Alan Düzeni }\end{array}$ & $\begin{array}{l}\checkmark \text { Bahçe mesafeleri veya ortak alanların } \\
\text { yeşil ve güvenli kullanımı olmayan bina yerleşimi } \\
\checkmark \text { Bahçe mesafeleri ve ortak alanların yeşil } \\
\text { ve güvenli kullanımı olan bina yerleşimi }\end{array}$ & 0 \\
\hline
\end{tabular}

Kaynak: Değerlendirme ölçütleri yazarlar tarafından oluşturulmuştur.

\section{Açık ve Yeşil Alanlar}

Açik ve yeşil alanlar iki ölçüt ile değerlendirilmiştir (Tablo 4). İlkinde, inceleme alanında yaşayan yaklaşık nüfus hesabına göre, $500 \mathrm{~m}$. erişilebilir mesafedeki kişi başına düşen yeşil alan miktarı göz önüne alınmıştır. Yeşil alanların asgari büyüklügü ülkemiz imar mevzuatına göre, $10 \mathrm{~m}^{2}$ olarak alınmıştır. 10 $\mathrm{m}^{2}$ den küçük yeşil alana sahip yerler hiç puan (0) alamazken, $10 \mathrm{~m}^{2}$ ve daha fazla yeşil alana sahip yerler en çok puanı (5) almıştır. İkincisinde, binalarda bahçenin varlığı ve kullanımı, çatılarda yeşillendirilmiş çatı-bahçesi oluşumları, evlerin 
önünde ve pencerelerde saksıların olması gibi durumları göz önüne alan yeşillendirme çabaları dikkate alınmıştır. Bu kriterin hiç olmaması durumuna puan verilmezken, biraz olması durumuna 3 puan, çok fazla olması durumuna 5 puan verilmiştir.

\section{Karma Kullanim}

Karma kullanımı ölçmek için konut dışı kullanımların varlığıyla ilgili iki tür ölçüte yer verilmiştir (Tablo 4). İlkinde, incelenen alandaki kişilerin ihtiyaçlarını karşılamaya yönelik günlük ticari faaliyetlerin adedi dikkate alınmıştır. Konutlara 500 m.'lik yürüme mesafesinde hiçbir konut dışı alanın olmadığı yerler hiç puan alamazken (0), konut dışı kullanımların 1-3 adet olmasına (3) ve 5'den fazla olmasına (5) göre giderek artan puanlar verilmiştir. İkinci ölçüt ise, alandaki çevre kalitesini düşürmesi nedeniyle, kirletici ve gürülttülü kullanımların ve etkenlerin varlığını ele almıştır. Bu etkenlerin sayısı 5 'den fazla ise hiç puan (0) verilmezken, 1-5 adet olan yerler orta derecede (3), hiç olmayan yerler en yüksek puanla (5) değerlendirilmiştir.

\section{Çeşitlilik}

İncelenen alanlarda çeşitliliği değerlendirmek için, kat yüksekliği, taban alanı ve dış cephe açısından etrafındaki konutlarla uyumlu olan ancak mimari özellikleri farklılaşan yapıların varlığına bakılmıştır (Tablo 4).

Tablo 4. Çalışmada Kullanılan Diğer Ölçütler

\begin{tabular}{|c|c|c|}
\hline Ölçütler / Alt-Ölçütler & Değerlendirme & Puan \\
\hline \multicolumn{3}{|l|}{ Açık ve Yeşil Alanlar } \\
\hline $\begin{array}{l}\qquad \text { Erişilebilir Açk } \\
\text { Yeşil Alanların } \\
\text { Büyü̈lüğ̈ü }\end{array}$ & $\begin{array}{ll}\checkmark & 10 \mathrm{~m}^{2} \text { den küçük } \\
\checkmark & 10 \mathrm{~m}^{2}-20 \mathrm{~m}^{2} \text { büyüklü̆̆̈̈ arasında } \\
\checkmark & 21 \mathrm{~m}^{2}-30 \mathrm{~m}^{2} \text { büyüklüğ̈ü arasında } \\
\checkmark & 31 \mathrm{~m}^{2}-50 \mathrm{~m}^{2} \text { büyüklüğü arasında } \\
\checkmark & 51 \mathrm{~m}^{2}-100 \mathrm{~m}^{2} \text { büyüklüğü arasında } \\
\checkmark & 100 \mathrm{~m}^{2} \text { veya daha fazla }\end{array}$ & $\begin{array}{l}0 \\
1 \\
2 \\
3 \\
4 \\
5\end{array}$ \\
\hline $\begin{array}{l}\quad \checkmark \text { Binalarda ve } \\
\text { Sokaklarda } \\
\text { Yeşillendirme }\end{array}$ & $\begin{array}{ll}\checkmark & \text { Yok } \\
\checkmark & \text { Kısmen-yeterli değil } \\
\checkmark & \text { Çok var-yeşil görüntü var }\end{array}$ & $\begin{array}{l}0 \\
3 \\
5\end{array}$ \\
\hline \multicolumn{3}{|l|}{ Karma Kullanım } \\
\hline $\begin{array}{l}\checkmark \text { Konut Dışı } \\
\text { Kullanım ) }\end{array}$ & $\begin{array}{ll}\checkmark & \text { Hiç yok } \\
\checkmark & 1-5 \text { adet var } \\
\vee & \text { 5'den fazla var }\end{array}$ & $\begin{array}{l}0 \\
3 \\
5\end{array}$ \\
\hline
\end{tabular}




\begin{tabular}{llll}
\hline \multicolumn{1}{c}{ Konut Dişı } & $\checkmark$ & 5'den fazla var & 0 \\
$\begin{array}{l}\text { Kullanım (Kirletici } \\
\text { etkenler) }\end{array}$ & $\checkmark$ & 1-5 adet var & 3 \\
\hline Çeşitlilik & $\checkmark$ Hiç yok & 5 \\
\hline & & \\
$\checkmark$ Dokuyla & $\checkmark$ & Hiç yok \\
Uyumlu Farklı Konut & $\checkmark$ & En az bir adet var & 0 \\
Tipleri & $\checkmark$ & 2-4 adet var & 1 \\
\hline
\end{tabular}

Kaynak: Değerlendirme ölçütleri yazarlar tarafından oluşturulmuştur.

\section{Inceleme Alanlarmın Seçimi}

İnceleme alanlarının seçiminde, Yıldırım ilçesinin geçmişten bugüne yaşadığı değişimler göz önüne alınmıştır. Tarihsel gelişim ve kentsel doku farkllıklarına göre, 6 morfolojik bölge elde edilmiştir. Kent merkezi, kentin iç çeperi, orta çeperi ve diş çeperine doğru tarihsel süreçte genişleyen ilçede, bu bölgelerin her birini temsil etmek üzere 6 mahalle ve bu mahallerde tipik yapı adası karakterini yansıtan alanlar rastgele seçilmiştir.

Yeşil Mahallesi, ilçenin Osmanlı dönemindeki en eski yerleşim bölgesi olan (1) numaralı morfolojik uyum bölgesini temsil etmektedir. Daha sonra, Yıldırım'ın kentleşmesi 1960'lardan sonra Bursa'da artan sanayileşmeye paralel olarak gerçekleşmiştir. 1970'lerden itibaren doğal eşiklere ulaşan kentte arsa fiyatları artarken, Yıldırım kente yeni gelenlerin yasal olmayan yollarla inşa ettikleri konutları barındırmaya başlamıştır. 1970-80'li yıllarda kentin doğu yönünde genişlemesiyle gelişen, günümüzde iç çeperde kalan (2) nolu bölgeyi temsilen Beyazıt Mahallesi seçilmiştir.

1987 yılında merkez ilçe statüsüne geçen Yıldırım 1990 - 2000 yılları arasında Bursa'daki en çok nüfus artışının yaşandığı ikinci ilçe olmuştur (TUIK, 2020a, 2020b). 1990 sonrasında, bir yandan ilçedeki kaçak yapılaşma artarken, diğer yandan konut sorununa planlı çözümler getirmeyi hedefleyen kooperatif yoluyla oluşan konut alanları görülmektedir (Ertürk ve Karakurt-Tosun, 2009). Siteler Mahallesi, 80-90'lı yıllarda, kentin doğuya doğru kooperatif yoluyla inşa edilen sitelerle genişlediği (3) nolu bölgeye örnek teşkil etmektedir.

2000'lerin başında kurulan Oto-Sansit Küçük Sanayi Sitesi gibi düzenli sanayilerin varlığının ilçede artmasına rağmen, daha önceki süreçlerde sanayi ve konut alanlarının iç içe olduğu pek çok mahalle halen varlığını sürdürmektedir. Kentteki sanayileşme faaliyetleriyle çeperde gelişen dağınık sanayilerle birlikte konutların 
iç içe yer aldığı (4) nolu bölge için Arabayatağı Mahallesi örnek alan olarak belirlenmiştir. Kentin dış çeperinde düzenli küçük sanayi sitesi (Oto-Sansit) yakınındaki, düzensiz konut alanlarının olduğu (5) nolu bölge için Şirinevler Mahallesi incelenmiştir.

2000'li yıllarda ilçede yaygin olan kaçak ve plansız yapılaşmalar kentsel dönüşüme konu olmaya başlamıştır (Illkme, 2009). Bu eğilimlerin görüldüğü son yıllarda, kentin kuzey çeperinde hızlı nüfus artısının yaşandığı (6) nolu bölgeyi temsilen Millet Mahallesi seçilmiştir.

Morfolojik uyum bölgeleri ve bunlar içerisinde seçilen mahallelerin kent içindeki konumları Şekil 1'de, seçilen yapı adalarındaki kentsel dokuya ilişkin uydu ve harita görüntüleri ise Şekil 2'de yer almaktadır.

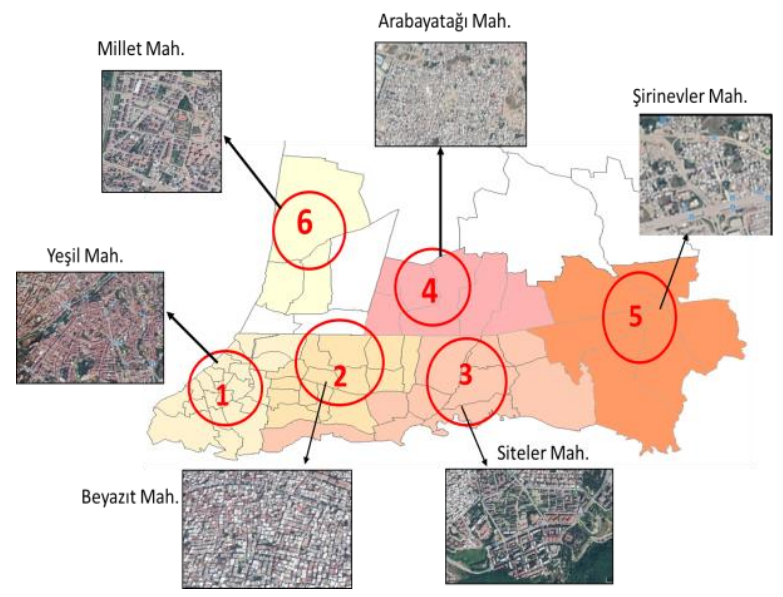

Şekil 1. Seçilen Örnek alanların Kent İçindeki Konumları (Kaynak: Google (2021) ve BYB (2020) verisi kullanılarak yazarlar tarafından üretilmiştir.)
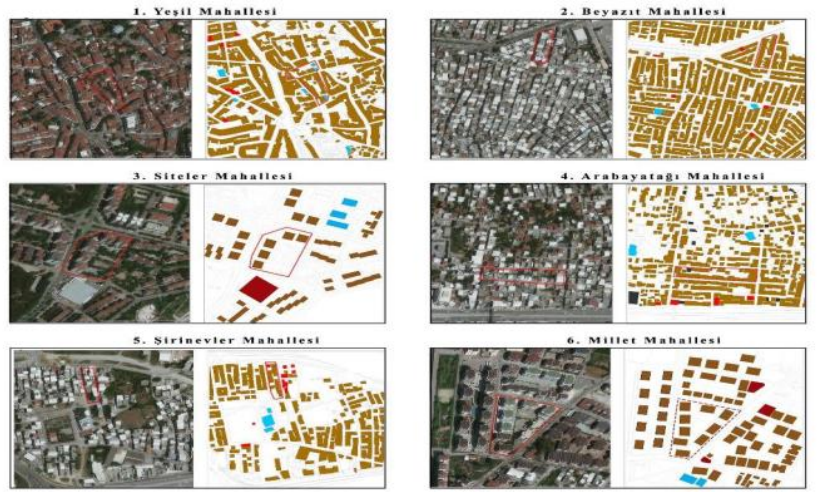

Şekil 2. Seçilen Alanlarda Kentsel Doku 
(Kaynak: Google (2021) ve BYB (2020) verileri kullanılarak yazarlar tarafından üretilmiştir.)

\section{Bulgular}

Çalışma kapsamında ele alınan altı mahalleye ilişkin yapılan analiz çalışmasının bulguları mahalle bazında seçilen yapı adalarında incelenmiştir. Kullanılan SKB ölçütlerinden tüm alanlarda en fazla karşılanan yoğunluk (\%80) ve karma kullanım $(\% 73,3)$ ölçütleridir. Bunları, geçirgenlik $(\% 58,9)$ ve erişilebilirlik (\%54) izlemektedir. Açık yeşil alanlar $(\% 48,3)$ ve çeşitlilik $(\% 16,7)$ açısından genel bir eksiklik bulunmaktadır (Tablo 5-6; Şekil 3).

Derişiklik-yoğunluk bakımından, brüt nüfus yoğunluğu (\%83,3) ve KAKS (\%80) en fazla karşılanan alt-ölçütlerdir. TAKS ile ilgili özellikle düzensiz yapılaşan yerlerde sorunlar gözlenmiştir. Derişiklik-yoğunluk ilkesini en fazla karşılayan en eski yerleşim birimlerinden olan Yeşil ve Beyazıt mahallelerini, düzenli konut alanlarından oluşan Siteler ve Millet mahalleleri izlemekte, en düşük oranlar ise, düzensiz gelişen Arabayatağı ve Şirinevler'de görülmektedir (Tablo 5). Erişilebilirlik ölçütleri içinde, yürünebilirlik (\%80) ve duraklara erişim ölçütleri $(\% 76,7)$ genel olarak yüksek değerler almıştır. En düşük puanlar, otopark alanları (\% 46,7), yaya dostu/güvenli yollar $(\% 43,3)$ ile bisiklet yolları $(\% 23,3)$ için bulunmuştur. Bu ölçüt için en yüksek puanı Siteler ve Millet alırken, en düşük puanı Arabayatağı almıştır (Tablo 5).

Geçirgenlik açısından, konutlara erişim $(\% 76,7)$ ve yapı adaları uzunluklarının (\% 66,7) genelde sağlanmasına rağmen, yeni gelişen alanlarda sorunlar bulunmuştur. Geçirgenliğin en fazla olduğu Siteler'dir. Siteler ve Millet mahallelerinde yapı adaları içerisindeki kütle ve açık alan düzeni olumlu iken, parsel bazında gelişen diğer alanlarda eksiklikler vardır (Tablo 5).

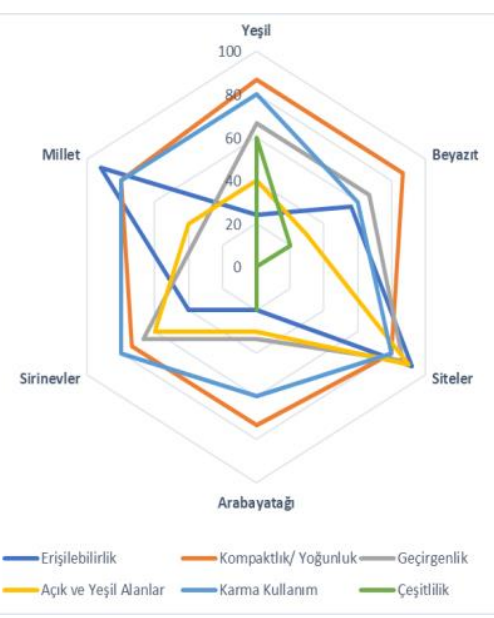


Şekil 3. SKB Ölçütlerinin İnceleme Alanlarındaki Değerleri (Kaynak: Yazarlar tarafından Alan Araştırması verileriyle üretilmiştir.)

Tablo 5. Derişiklik-Yoğunluk, Erişilebilirlik ve Geçirgenlik Bulguları

\begin{tabular}{|c|c|c|c|c|c|c|c|c|}
\hline & & & İnceleme & lanları & & & Ölçüt Ort & ama Değerleri \\
\hline $\begin{array}{l}\text { Ölçütler/ } \\
\text { Alt Ölçütler }\end{array}$ & $\begin{array}{c}1 \\
\text { Yeşil }\end{array}$ & $\begin{array}{c}2 \\
\text { Beyazit }\end{array}$ & $\begin{array}{c}3 \\
\text { Siteler }\end{array}$ & $\begin{array}{c}4 \\
\text { Araba } \\
- \\
\text { yatağ1 }\end{array}$ & $\begin{array}{c}5 \\
\text { Şirin- } \\
\text { evler }\end{array}$ & $\begin{array}{c}6 \\
\text { Millet }\end{array}$ & Ortalama & $\begin{array}{c}\text { Kriterin Karşı- } \\
\text { lanma Oramı } \\
(\%)\end{array}$ \\
\hline \multicolumn{9}{|l|}{ Derişiklik/Yoğunluk } \\
\hline a) Brüt Nüfus Yoğunluğu & 4 & 5 & 4 & 4 & 4 & 4 & 4,2 & 83,3 \\
\hline b) TAKS & 4 & 3 & 5 & 3 & 4 & 4 & 3,8 & 76,7 \\
\hline c) $\mathrm{KAKS}$ & 5 & 5 & 3 & 4 & 3 & 4 & 4,0 & 80,0 \\
\hline Ortalama & 4,3 & 4,3 & 4,0 & 3,7 & 3,7 & 4,0 & 4,0 & 80,0 \\
\hline $\begin{array}{l}\text { Kriterin Karşılanma } \\
\text { Oranı }(\%)\end{array}$ & 86,7 & 86,7 & 80,0 & 73,3 & 73,3 & 80,0 & 80,0 & \\
\hline \multicolumn{9}{|l|}{ Erişilebilirlik } \\
\hline i. Yürünebilirlik & 3 & 5 & 5 & 1 & 5 & 5 & 4,0 & 80,0 \\
\hline $\begin{array}{ll}\text { a) Yaya } & \text { ii. Yaya dostu ulaşım } \\
\text { Erişimi } & \text { sistemi }\end{array}$ & 0 & 3 & 5 & 0 & 0 & 5 & 2,2 & 43,3 \\
\hline iii. Duraklara erişim & 2 & 5 & 5 & 2 & 4 & 5 & 3,8 & 76,7 \\
\hline $\begin{array}{l}\text { b) Otomobil } \\
\text { (Otopark Alani) }\end{array}$ & 1 & 1 & 5 & 1 & 1 & 5 & 2,3 & 46,7 \\
\hline c) Bisiklet & 0 & 0 & 3 & 1 & 0 & 3 & 1,2 & 23,3 \\
\hline Ortalama & 1,2 & 2,8 & 4,6 & 1 & 2 & 4,6 & 2,7 & 54,0 \\
\hline $\begin{array}{l}\text { Kriterin Karşılanma } \\
\text { Oranı }(\%)\end{array}$ & 24,0 & 56,0 & 92,0 & 20,0 & 40,0 & 92,0 & 54,0 & \\
\hline \multicolumn{9}{|l|}{ Geçirgenlik } \\
\hline a) Yapı adası uzunluğu & 5 & 5 & 5 & 0 & 5 & 0 & 3,3 & 66,7 \\
\hline $\begin{array}{l}\text { b) Konutlara Erişim- (duvar-sınır- } \\
\text { açı/kapalı) }\end{array}$ & 5 & 5 & 3 & 5 & 5 & 0 & 3,8 & 76,7 \\
\hline c) Kütle ve Açı Alan Düzeni & 0 & 0 & 5 & 0 & 0 & 5 & 1,7 & 33,3 \\
\hline Ortalama & 3,3 & 3,3 & 4,3 & 1,7 & 3,3 & 1,7 & 2,9 & 58,9 \\
\hline $\begin{array}{l}\text { Kriterin Karşılanma } \\
\text { Oranı }(\%)\end{array}$ & 66,7 & 66,7 & 86,7 & 33,3 & 66,7 & 33,3 & 58,9 & \\
\hline
\end{tabular}

(Kaynak: Yazarlar tarafından Alan Araştırması verileriyle üretilmiştir.)

Açk ve yeşil alanlarla ilgili ölçütler içinde en fazla karşılanan yeşillendirme (\%6 6.7) ölçütünü en çok sağlayan mahalle Siteler'dir. Konut dışı ticaret ve kamusal hizmetlerin olduğu karma kullanım ölçütü Beyazıt ve Arabayatağı dışındaki tüm alanlarda yüksektir. Arabayatağı'nda kirletici ve gürültü yapıc etkenler olumsuz puan almasına neden olmuştur. Çeşitlilik en fazla Yeşil'de karşılanırken, hiç puan alamayan alanlar, düzenli yapılaşan Siteler ve Millet ile kent çeperindeki Şirinevler olmuştur (Tablo 6). 
Tablo 6. Açık-Yeşil Alanlar, Karma Kullanım ve Çeşitlilik Bulguları

\begin{tabular}{|c|c|c|c|c|c|c|c|c|}
\hline \multirow[b]{2}{*}{$\begin{array}{l}\text { Ölçütler / } \\
\text { Alt Ölçü̈ller }\end{array}$} & \multicolumn{6}{|c|}{ İnceleme Alanları } & \multicolumn{2}{|c|}{ Ölçüt Ortalama Değerleri } \\
\hline & $\begin{array}{c}1 \\
\text { Yeşil }\end{array}$ & $\begin{array}{c}2 \\
\text { Beyaz } \\
\text { it }\end{array}$ & $\begin{array}{c}3 \\
\text { Siteler }\end{array}$ & $\begin{array}{c}4 \\
\text { Araba } \\
- \\
\text { yatağ1 }\end{array}$ & $\begin{array}{c}5 \\
\text { Şirin- } \\
\text { evler }\end{array}$ & $\begin{array}{c}6 \\
\text { Millet }\end{array}$ & Ortalama & $\begin{array}{c}\text { Kriterin } \\
\text { Karşılanma } \\
\text { Oranı (\%) }\end{array}$ \\
\hline \multicolumn{9}{|l|}{ Açık ve Yeşil Alanlar } \\
\hline a) Yeşil Alan Büyüklüğü & 1 & 0 & 4 & 0 & 3 & 1 & 1,5 & 30,0 \\
\hline b) Yeşillendirme & 3 & 3 & 5 & 3 & 3 & 3 & 3,3 & 66,7 \\
\hline Ortalama & 2,0 & 1,5 & 4,5 & 1,5 & 3,0 & 2,0 & 2,4 & 48,3 \\
\hline Kriterin Karşılanma Oranı $(\%)$ & 40,0 & 30,0 & 90,0 & 30,0 & 60,0 & 40,0 & 48,3 & \\
\hline \multicolumn{9}{|l|}{ Karma Kullanım } \\
\hline a) Konut dışı kullanım & 3 & 3 & 5 & 3 & 5 & 5 & 4,0 & 80,0 \\
\hline b) Kirletici etkenler & 5 & 3 & 3 & 3 & 3 & 3 & 3,3 & 66,7 \\
\hline Ortalama & 4,0 & 3,0 & 4,0 & 3,0 & 4,0 & 4,0 & 3,7 & 73,3 \\
\hline Kriterin Karşılanma Oranı (\%) & 80,0 & 60,0 & 80,0 & 60,0 & 80,0 & 80,0 & 73,3 & \\
\hline \multicolumn{9}{|l|}{ Çeşitlilik } \\
\hline a) Farklı konut türleri & 3 & 1 & 0 & 1 & 0 & 0 & 0,8 & 16,7 \\
\hline Kriterin Karşılanma Oranı (\%) & 60 & 20 & 0 & 20 & 0 & 0 & 16,7 & \\
\hline
\end{tabular}

(Kaynak: Yazarlar tarafından Alan Araştırması verileriyle üretilmiştir.)

İncelenen alanlarda tüm ölçütleri en fazla karşılayan Siteler (\%71.4) iken, en az karşılayan Arabayatağı olmuştur. Tüm alanlarda SKB ölçütlerinin ortalama \% 55.2'si karşılanmıştır (Tablo 7).

Tablo 7. Tüm Ölçütlerin Karşılanma Oranları

\begin{tabular}{|c|c|c|c|c|c|c|c|c|}
\hline \multirow[b]{2}{*}{ Tüm Ölçütler } & \multicolumn{6}{|c|}{ İnceleme Alanları } & \multicolumn{2}{|c|}{ Ölçüt Ortalama Değerleri } \\
\hline & $\begin{array}{c}1 \\
\text { Yeşil }\end{array}$ & $\begin{array}{c}2 \\
\text { Be- } \\
\text { yazıt }\end{array}$ & $\begin{array}{c}3 \\
\text { Site- } \\
\text { ler }\end{array}$ & $\begin{array}{c}4 \\
\text { Arab } \\
\text { a-ya- } \\
\text { tağı }\end{array}$ & $\begin{array}{c}5 \\
\text { Şi- } \\
\text { rin- } \\
\text { evler }\end{array}$ & $\begin{array}{c}6 \\
\text { Mil- } \\
\text { let }\end{array}$ & Ortalama & $\begin{array}{c}\text { Kriterin Kar- } \\
\text { şılanma } \\
\text { Oranı (\%) }\end{array}$ \\
\hline Ortalama & 3,0 & 2,7 & 3,6 & 2,0 & 2,7 & 2,7 & 2,8 & 55,2 \\
\hline $\begin{array}{l}\text { Kriterlerin Karşılanma Oranı } \\
(\%)\end{array}$ & 59,6 & 53,2 & 71,4 & 39,4 & 53,3 & 54,2 & 55,2 & \\
\hline
\end{tabular}

(Kaynak: Yazarlar tarafından Alan Araştırması verileriyle üretilmiştir.)

\section{Yeşil Mahallesi}

Yeşil Mahallesi'nde incelenen yapı adasında, brüt nüfus yoğunluğu 550 kişi/ha, taban alanı kat sayısı 0.60 iken, toplam inşaat alanı 1.95'tir. Taban alanı kullanımı açısından, açık alanların oranı nispeten azdır. Bunun nedeni, geleneksel dokunun yerini alan apartmanların küçük parseller üzerinde ve 
parseli tamamen kaplayan yapılaşmasıdır. Halen korunan geleneksel konutlar düşük katlı ve bahçeli yapılardan meydana gelirken, çoğunluğu bakımsız ve köhnemiştir. Sonradan yapılan 3-4 katlı apartman yapılarının ise, bir kısmında eskime sürecinin başladığ 1 ve dış cephelerinin bakımsızlığı dikkat çekmektedir. Apartmanlar, alandaki nüfus yoğunluğunu arttırmakla kalmamış, mevcut dar sokak dokusundaki yola sıfır cepheleri, yaya ve araç erişilebilirliğini kısıtlamıştır.

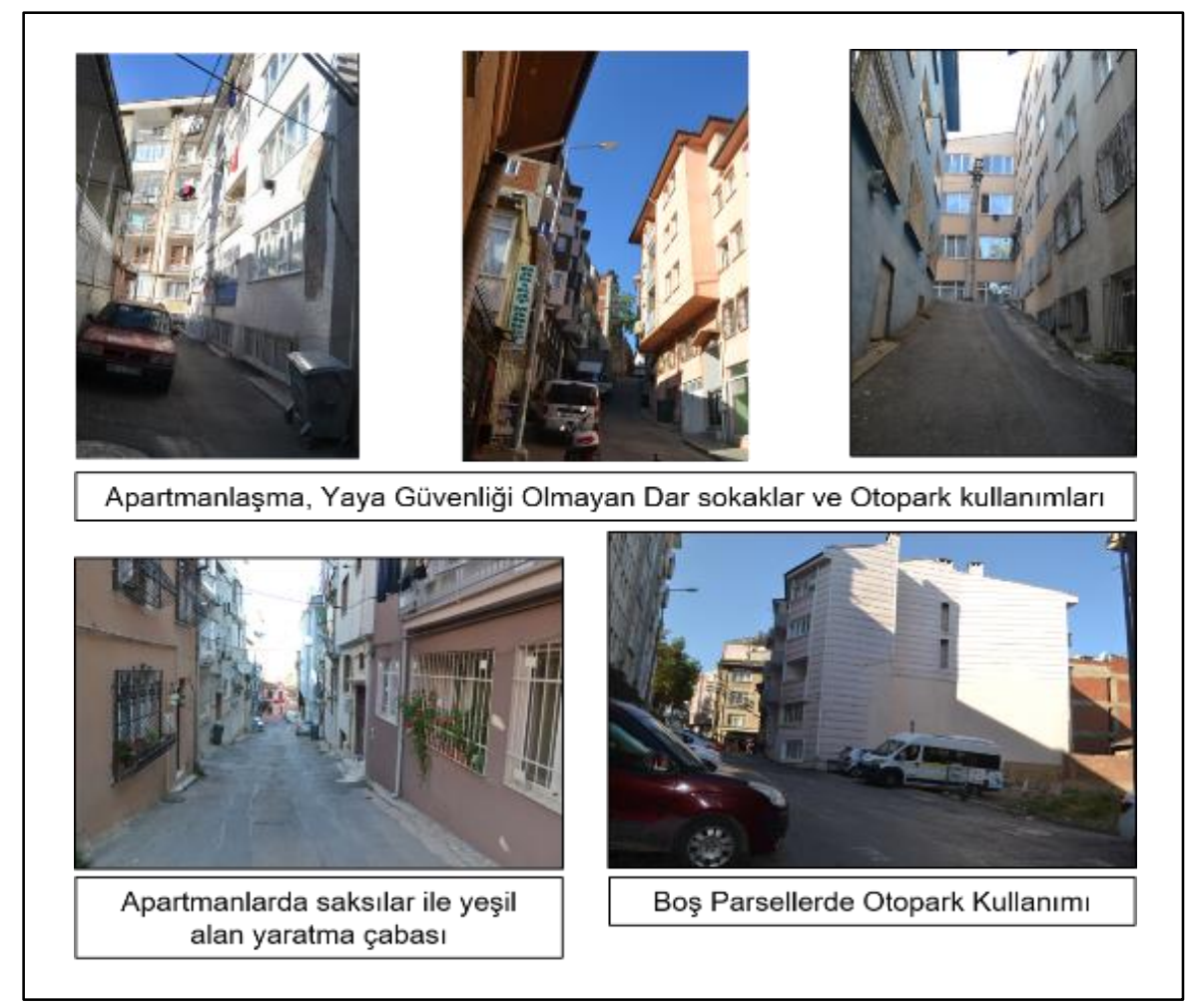

Şekil 4. Yeşil Mahallesi Kentsel Çevre Özellikleri

(Kaynak: Yazarlar, 2020)

Yaya kaldırımları kaybolurken, özel araçlar için ayrılan park alanlarının eksikliği, yol kenarlarına ve/veya boş parsellere araçların park etmesine neden olmakta, yaya güvenliğini azaltmaktadır. İncelenen ada çevresinde az sayıda eczane, sağlık ocağı ve bakkal gibi işlevlerin olması karma kullanımın kısmen varlığını göstermektedir. Alan, karma kullanımın yoğun olduğu ana caddeye yakın olmasına rağmen, eğim gibi önemli bir eşiğin varlığı, yaya ve araçların erişilebilirliğini azaltmaktadır. Yapı adası içinde veya yakınında or- 
tak ve kamusal açık ve yeşil alan eksikliğine karşın, bazı apartman sakinlerinin cam kenarlarında saksı bitkileriyle yeşillendirme çabalarına rastlanmıştır. Alanda eski tarihi evlerle birlikte apartmanların bir arada olması çeşitlilik nedeni iken, bunlar parsel kullanımı ve yükseklik açısından uyum sağlayamamiştır.

\section{Beyazit Mahallesi}

Beyazıt Mahallesi'nde incelenen yapı adasında brüt nüfus yoğunluğu 672 kişi/ha, TAKS 0.68, KAKS 1.90'dır. Nüfusun yoğun olmasına rağmen, binaların kapladığı taban alanı oranının nispeten fazla olması sürdürülebilirliği azaltmaktadır. Alanda yer alan binaların, dar sokaklar ve arka cephelerde birbirine oldukça yaklaşması, hisseli mülkiyetten kaynaklanan yapılaşma biçimini temsil etmektedir. Küçük ve dar parseller üzerindeki 3-4 katlı yapıların ön ve arka cephesinde kendine yer bulamamış yeşil alanlar, cadde üzerindeki refüjlerde ve binaların teraslarında asma vb. öğelerle izlenmektedir. Ancak, bu terasların bir süre sonra, yapının iç mekânına katıldığı inşaat çalışmalarına rastlanmıştır. Yapı adasının ana caddeye erişim gibi olumlu özelliklerine rağmen, otopark eksikliği nedeniyle özel araçların sokak üzerinde park edilmesi ve kaldırımların dar ve süreksiz olması, yaya erişebilirliğini ve güvenliğini olumsuz etkilemektedir. Yapı adasında ticari bir faaliyet ve karma kullanım özelliği bulunmazken, yakın çevresinde yürüme mesafesindeki komşu yapı adalarında farklı işlevler ve donatılar bulunmaktadır.

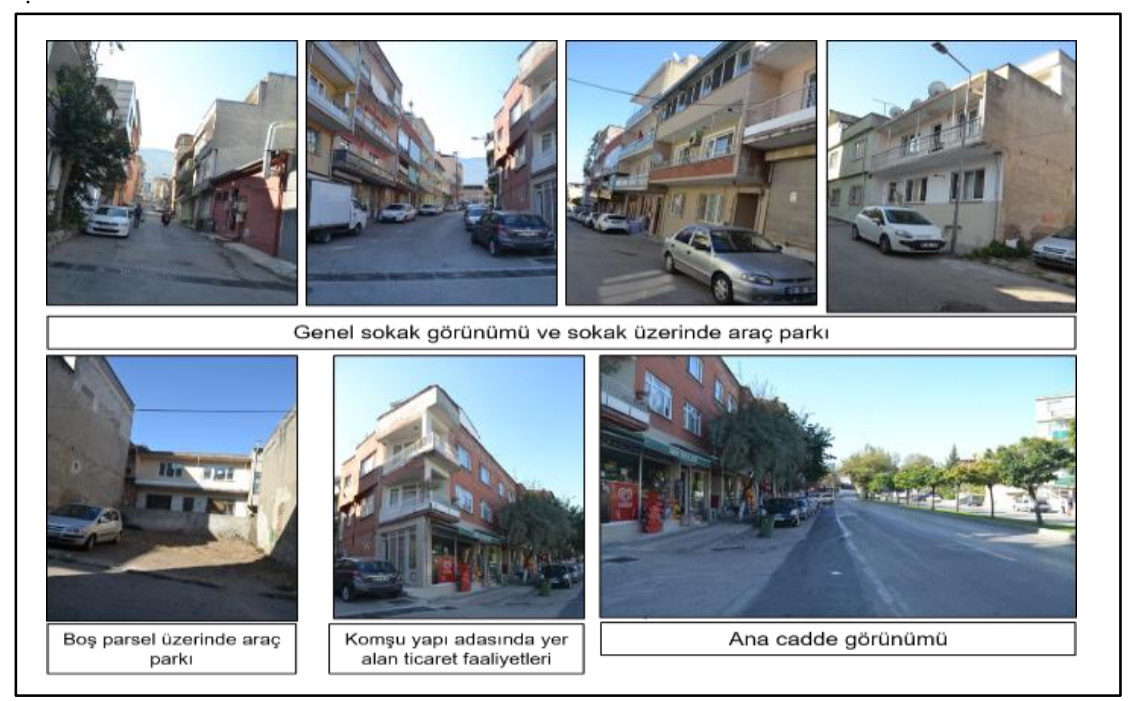

Şekil 5. Beyazıd Mahallesi Kentsel Çevre Özellikleri

(Kaynak: Yazarlar, 2020) 


\section{Siteler Mahallesi}

Planlı gelişen mahallede incelenen yapı adası kooperatif yoluyla inşa edilmiş klasik yani kapalı olamayan bir sitedir. Toplam 13 adet 9 katlı binanın yer aldığ1 yapı adasında TAKS 0.25, KAKS 1.75, brüt nüfus yoğunluğu ise 447 kişi/ha'dır. Konutların yerleşimi yarı-kamusal açık/yeşil alanlara sahip bir kentsel örüntüyü sağlamaktadır. Yapı adasında binaların homojenliği nedeniyle çeşitlilik olmamasına rağmen, açıklıklar ve eğime uygun peyzaj düzenlemeleri sayesinde monotonluk hissedilmemektedir. Ortak alanların büyük bir kısmı, açık-yeşil alan ve spor alanı olarak bir kısmı ise otopark olarak ayrılmıştır. Yapı adasının dolmuş ve otobüslerin sık geçtiği bir mevkide ana caddeye cephesinin olması, erişilebilirliğini arttırmaktadır.

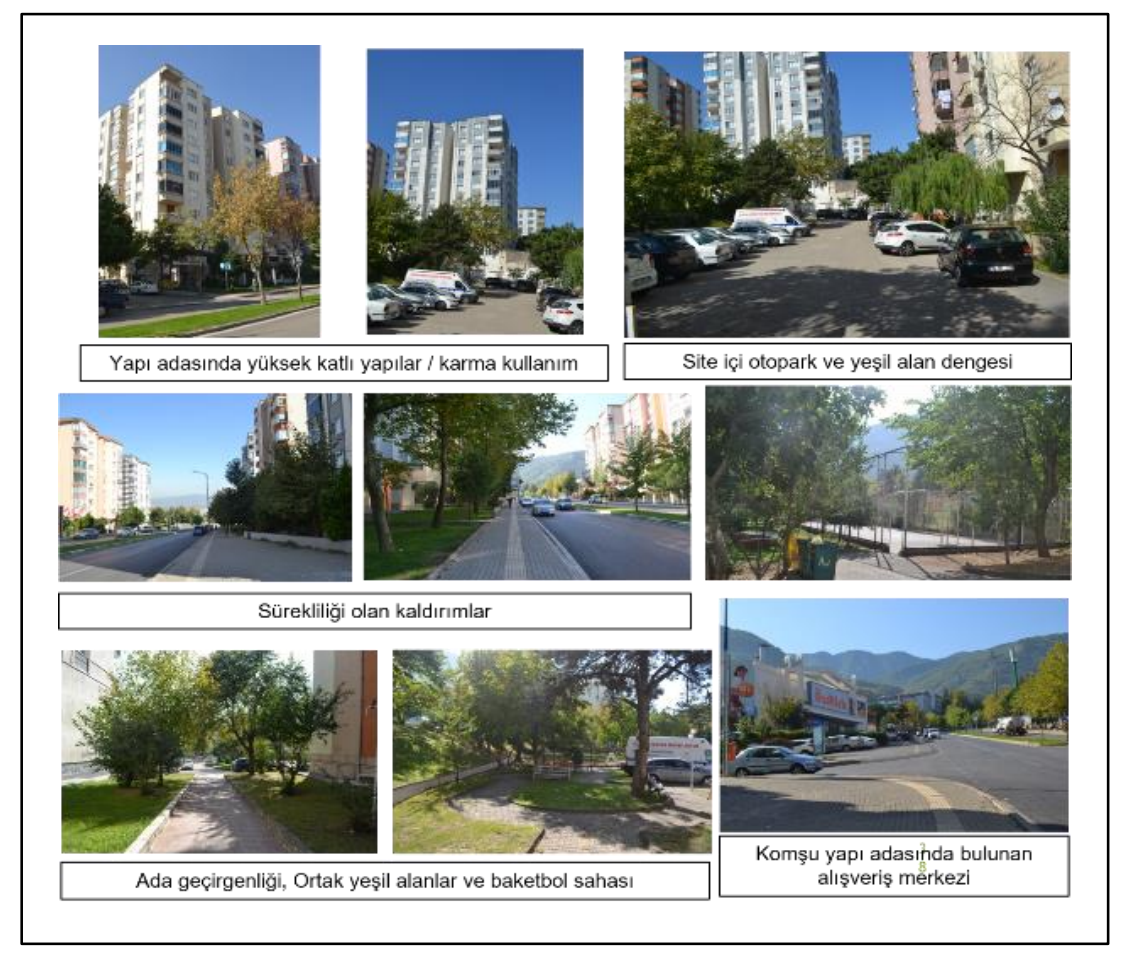

Şekil 5. Siteler Mahallesi Kentsel Çevre Özellikleri

(Kaynak: Yazarlar, 2020)

Cadde üzerinde ve yapı adası içerisinde, taşıt ve yaya mekânlarının birbirinden ayrılmasıyla birlikte, yaya yolları ve kaldırımların sürekliliği ve genişliği, erişilebilirlik açısından diğer olumlu özelliklerdir. Ayrıca, yapı adası içe- 
risine birçok yerden geçiş sağlanması ve eğimle ilgili eşiklerin peyzaj düzenlemeleriyle çözülmesi, geçirgenliği arttırmaktadır. Yapıların ana caddeye bakan cephelerinde kafe, market gibi ticaret işlevlerinin yer alması nedeniyle karma kullanım özelliği bulunmaktadır. Yürüme mesafesinde yerel bir market zincirinin büyük bir şubesi bulunmaktadır.

\section{Arabayatağı Mahallesi}

19. yüzyılda göçmenler tarafından bir köy olarak kurulan mahalle, günümüzde küçük sanayi birimleri ve konutların bir arada bulunduğu sıkışık bir dokuya sahiptir. İncelenen yapı adasında, 31 adet 3-4 katlı yapı yer almaktadır. Yapı adasındaki TAKS 0.61 iken, KAKS 1.75, brüt nüfus yoğunluğu 462 kişi/ha'dır. Genel olarak ticari işlevlerin varlığı, sosyal bir canlılık getirmekte, ancak dar sokaklardaki trafik, yaya kaldırımlarının eksikliği ve süreksizliği ile yol üzerinde park edilen araçlar, yaya ve araç geçişini engellediği için yürünebilirliği azaltmaktadır.

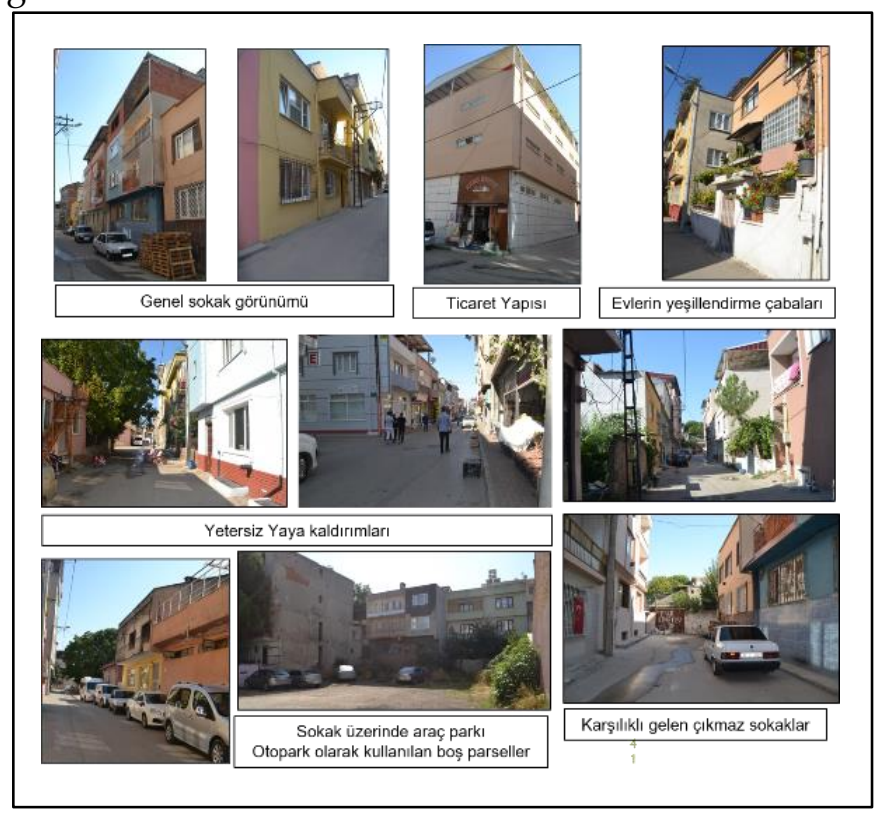

Şekil 7. Arabayatağı Mahallesi Kentsel Çevre Özellikleri

(Kaynak: Yazarlar, 2020)

Alanda yer alan karma kullanım türleri arasında gürültü ve kirliliğe neden olan üretimler bulunmaktadır. Dar parsellerde, yola sıfır cepheli binaların ağırlıklı olduğu yapı adasında, az sayıda bahçeli konut bulunmakta, bazı binaların girişlerinde saksı bitkileri ile yeşillendirme çabaları izlenmektedir. Araç trafiğini 
azaltan çıkmaz sokaklar, çocuklar için oyun, araçlar için otopark alanları oluşturmakla beraber geçirgenlik ve erişilebilirlik sorununa neden olmaktadır.

\section{Şirinevler Mahallesi}

En diş çeperde yer alan Şirinevler Mahallesi'nde incelenen yapı adası 3-4 katlı 16 adet müstakil binadan oluşmaktadır. Yapı adasının TAKS'1 0.54, KAKS' 1.41 ve brüt nüfus yoğunluğu 430 kişi/ha'dır. Bu özellikleriyle, sürdürülebilirlik açsindan uygun yoğunluk ve derişikliğe sahiptir. Ancak, dar parsellerdeki binaların cepheleriyle tanımlanan sokaklarda süreksiz ve dar kaldırımlar bulunmakta, kaldırımlar üzerindeki elektrik direkleri ve kabloları, yayaların güvenli kullanımın engellemektedir. Bazı binaların, özellikle köşe parsellerin bahçeleri olmasına rağmen, bunların bakımsızlığı dikkat çekmektedir. Yapı adası içerisinde ve çevresinde genel bir yeşil alan karakteri olmamasına rağmen, evlerin bazılarında teras kullanımı görülmüştür. Ayrıca, yapı adasının yakın çevresinde yürüme mesafesinde bulunan açık kamusal yeşil alan, çocuk oyun alanı, cami ve geniş boşluklu alanlara rastlanmaktadır. Boş parseller ve yakın çevredeki boş (atıl) ve geniş alanlar otopark olarak kullanılmaktadır. Yürüme mesafesindeki karma kullanımların ve açık-kamusal alanların varlığı, alanda canlılık ve sosyal hareketlilik oluşturmaktadır.

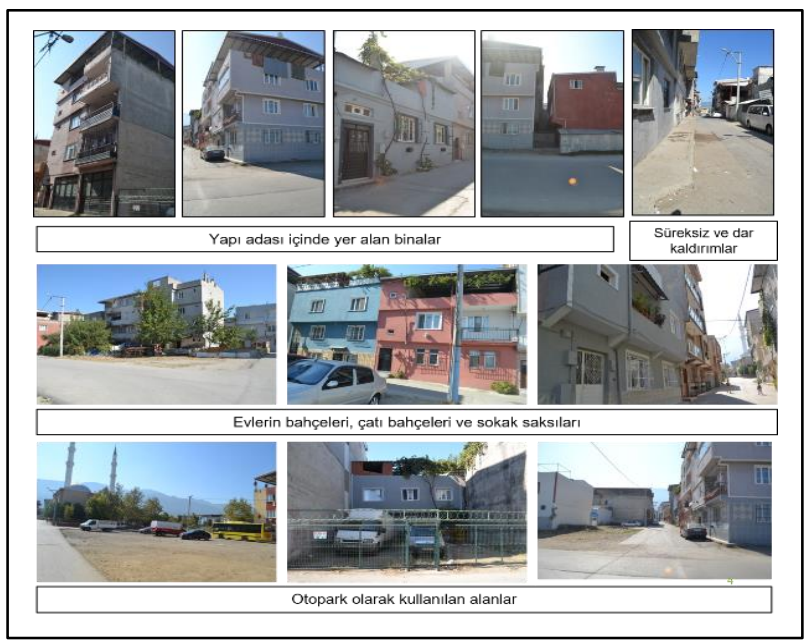

Şekil 8. Şirinevler Mahallesi Kentsel Çevre Özellikleri

(Kaynak: Yazarlar, 2020)

\section{Millet Mahallesi}

Millet Mahallesi, önceleri hisseli mülkiyet ile saçaklanma şeklinde ve kırsal denilebilecek nitelikte yer alan konut dokusuna sahip iken, son yıllardaki 
hızlı nüfus artışıla birlikte, alandaki boş araziler üzerinde kapalı sitelerin yapılmasıyla mahallenin dokusu değişmektedir. İncelenen yapı adası, mahallenin son yıllardaki değişen örüntüsünü temsil etmektedir. Alanda, TAKS 0.45, KAKS 1.2, brüt nüfus yoğunluğu 350 kişi/ha olarak ölçülürken, sürdürülebilir bir yoğunluğa işaret etmektedir. Yapı adasında ana caddeye cephesi olan binaların zemin katlarında kafe, restoran gibi ticaret faaliyetleri yer alırken, arka cadde kullanımlarında market, spor salonu gibi işlevlere rastlanmıştır. Yapı adasının içerisindeki konut girişleri ortak alanlardan sağlanırken, bu alanlara giriş sadece belirli noktalarda güvenlik görevlisi veya uzaktan kumandalı kapılar ile kontrollü olarak sağlanmaktadır. Geçirgenlik ayrıca sitelerin kendi tercihlerine göre belirledikleri duvar ve tel çit gibi kısıtlayıcılarla azaltılmıştır.

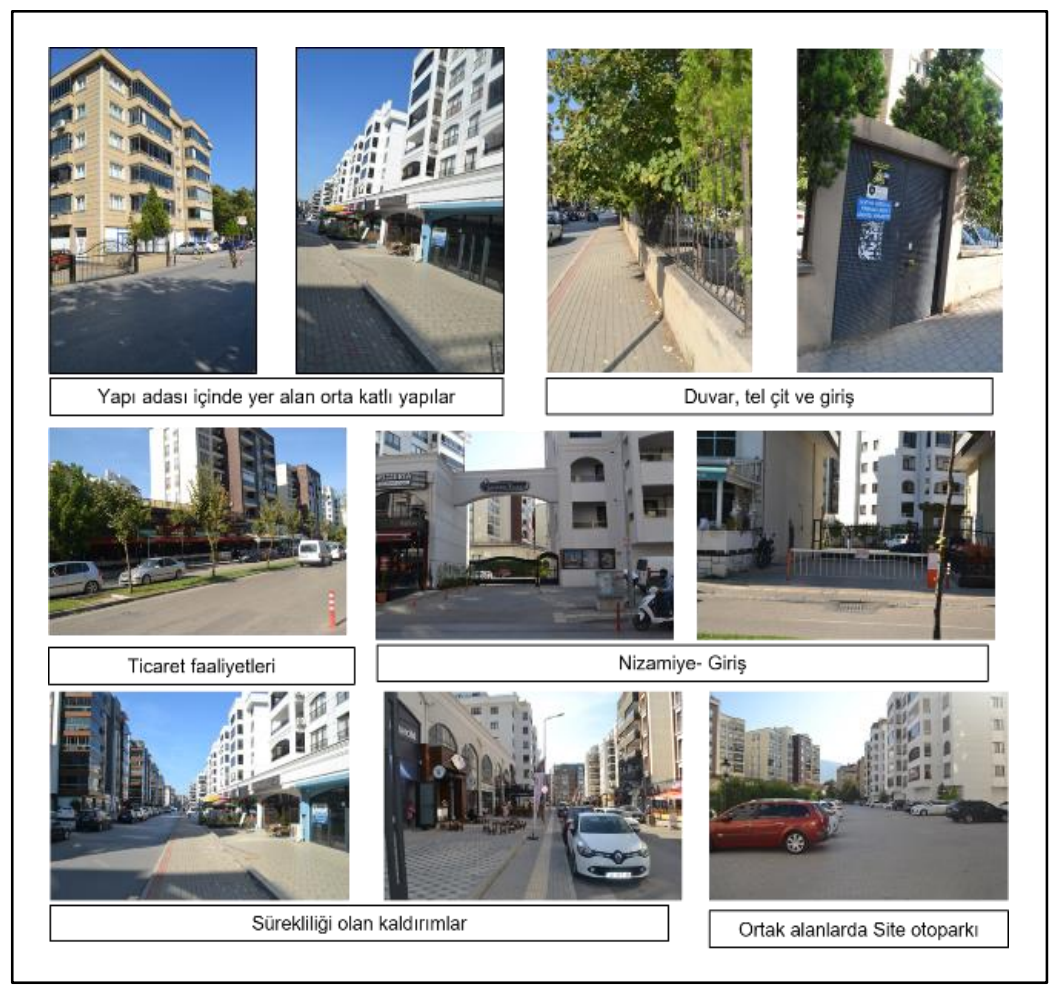

Şekil 9. Millet Mahallesi Kentsel Çevre Özellikleri

(Kaynak: Yazarlar, 2020)

Buna rağmen, yaya yolu ve araç trafiğinin birbirinden ayrılması, düzenli ve sürekli kaldırımların olması ve toplu taşıma olanakları açısından olumlu özellikler gözlenmiştir. Konut sitelerinin kendi ortak alanlarında otopark sağlaması, alışverişe gelenlerin ise yol kenarlarında park etmesi sayesinde, araç 
erişimi ve otopark sorunu kısmen çözülmüştür. Mahalle, sosyal ve ticari alanlarla büyümekte, ancak dokuda yeşil alan eksikliği dikkat çekmektedir. Konutların ortak kullanım alanlarında yeşil alanlara çok az yer verilirken, bu alanlar ağırlıklı olarak otopark amacıyla kullanılmaktadır. Çocukların genelde otopark alanlarında oynadığı gözlenmiştir. Alanda, beş katlı binaların, mimari açıdan benzer olması ve farklı kullanıclara hitap eden konutlar barındırmaması çeşitliliği azaltmıştır.

\section{Değerlendirme ve Sonuç}

Şehir planlamanın mekân üretme pratiğiyle doğrudan ilgili olan fiziksel yapılı çevrenin kalitesi kentlerdeki yaşam kalitesini doğrudan etkilemektedir. Son yıllarda, bir yandan yaşam kalitesi kavramı sürdürülebilirlikle yeniden önem kazanmış, diğer yandan sürdürülebilir kentleşme yaklaşımları ve sertifika programlarının gelişmesiyle fiziksel çevredeki kalite kavramı sürdürülebilir kentsel biçim (SKB) ilkelerine dayanan tasarım ve performans konusunu gündeme getirmiştir. Bu makale, SKB ilke ve ölçütlerini kentsel tasarım yazını, LEED-ND sertifika programı ve ülkemiz imar mevzuatı çerçevesinde değerlendirmiştir. Çok sayıdaki ölçüt arasından, derişiklik-yoğunluk, erişilebilirlik, geçirgenlik, açık-yeşil alanlar, karma kullanım ve çeşittilik ölçütleri SKB'i yapı adası bazında nesnel olarak değerlendirmek üzere seçilmiş; ölçütlere ağırlık verilmesi çalısmanın kapsamı dışında bırakılmıştır.

İncelenen konut alanları, Bursa Yıldırım ilçesinde, farklı kentsel doku özelliklerine sahip morfolojik uyum bölgelerini temsil eden yapı adalarıdır. Bunlar, kentin en eski ve merkezi yerleşim bölgesi (Yeşil), iç çeperde gelişen düzenli (Siteler) ve düzensiz (Beyazıd) konut alanları ile dış çeperdeki düzensiz (Arabayatağı ve Şirinevler) ve düzenli (Millet) konut alanlarını içermektedir.

Bulgulara göre, alanların tümünde en fazla derişiklik-yoğunluk ve karmakullanım ölçütleri sağlanırken, en az sağlanan açık-yeşil alanlar ve çeşitliliktir. Seçilen alanlar, yasal ve toplumsal süreçlerle gelişimine ve kent içindeki konumlarına göre farklı performans göstermişlerdir.

Kent merkezinde Yeşil mahallesinde, geleneksel dokunun kaybedilmesi, sadece tarihi kültürel mirasın ve yaşam biçimlerinin değil, sürdürülebilir kent biçiminin de yitirilmesiyle sonuçlanmıştır. Bahçeli az katlı konut tipolojisinden parsele binanın oturduğu apartmanlaşmaya doğru değişim, sadece özel mülkiyetteki açık-yeşil alanların kaybolmasına ve tarihi kimliğin yitirilmesine yol açmamıştır. Aynı zamanda, sokakların daraldığı kent dokusunda, araç ve yaya dolaşımı ile otopark sorunlarına neden olmuştur. 
En iyi performansı gösteren SKB'e sahip olan iç çeperdeki klasik (açı) site dokusu bulunan Siteler Mahallesi düzenli ve yasal gelişmiş bir konut alanıdır. Erişilebilirlik, geçirgenlik, yoğunluk ve açık yeşil alanlarla ilgili ölçütlerde yüksek puan almıştır. Kentin lineer gelişiminde, dış çeperde olmasına rağmen kent merkezine erişilebilirliği yüksek olan ve 2000'lerden sonra yeni gelişen kapalı sitelerin yer aldığı Millet Mahallesi ise, yoğunluk ve karma kullanımın fazla olmasına rağmen, geçirgenlik ve açık yeşil alanlar açısından düşük performans göstermiştir.

En düşük performansı gösteren SKB, iç çeper'deki Beyazıd Mahallesinde ve orta çeperdeki Arabayatağı Mahallesindeki konut alanlarında bulunmuştur. Beyazıd ve Arabayatağı'nda yataydaki yoğun yapılaşma, ada içi ve yakınındaki yeşil alanların eksikliğiyle birlikte açk alanlar açısından sorun oluşturmaktadır. Dış çeperdeki Şirinevler Mahallesi düzensiz bir konut alanı olmasına rağmen, kent içindeki kadar yapılaşma baskısı olmadığı için, açı alanların varlığı nedeniyle orta derecede SKB'e sahiptir.

Bulgular doğrultusunda farklı tipoloji ve kentsel konuma sahip alanlar için imar mevzuatında geliştirilmesi gereken konular hakkındaki öneriler şunlardır:

Yapı adası bazında gelişen alanlar: Konut kooperatifleri ve kapalı siteler olarak yapı adası bazında gelişen alanlarda, yapı adalarının ve bunlar içerisinde yer alacak konut komşuluk birimlerinin büyüklüğü, yapı adası uzunluğu (maximum 400 m.), kapalılık oranı (alana giriş-çıkışlar) gibi konularda imar mevzuatında standartların tanımlanması gerekmektedir. Ayrica, ortak alan kullanımlarında yeşil alan, yaya ve araç kullanımı açısından kentsel tasarım ilkelerine ihtiyaç bulunmaktadır. Bu tür alanlardaki konut sitelerinin kent içindeki konumuna (merkez, iç ve dış çeper gibi) göre imar mevzuatında SKB ölçüt ve standartlarında farklılıklar tanımlanabilir. Diğer yandan, binaların yere özgü özelliklerinin olması ve çeşitlilik sunmasının sağlanması, planlama, mimarlık ve inşaat uygulamalarında göz önüne alınması gereken bir husustur. Bunun için, bu tür ada bazında üretilen konut alanlarında, konutların farklı gelir gruplarına hitap edecek şekilde ve dokuyla uyumlu olarak çeşitlendirilmesini sağlayacak bazı gereklilikler imar mevzuatında tanımlanabilir.

Parsel bazında kaçak gelişen alanlar: Esasen imar mevzuatında parsel bazında bahçe mesafeleri ve yoldan cephelerin tanımlanması için araçlar bulunmaktadır. Ancak, uygulamada düzensiz gelişen alanlarda sonradan getirilen imar afları ve barışları ile pek çok kusur affedilmektedir. Bunların önüne geçmek için sağlıksız yapılaşmış alanlarda değişim ve dönüşümler, belirlenecek minimum standartlara göre sağlanabilir. Ancak, parselin ötesinde çözümler getirilmediği sürece, mevcut yoğunluk ve düzensizlikle ilgili sorunlar artacaktır. En az 
yapı adası düzeyinde ve/veya belirli bir konut komşuluğu düzeyinde uygulanabilecek standartlar gereklidir. Bunun için, imar mevzuatında yapı adalarının minimum ve maximum uzunluklarına, yapı adası ve parsellerde, ayrık veya bitişik nizamda yapılaşma düzeni türüne göre, binalar arasında bırakılması gereken boşluklara, ön-arka bahçe mesafelerine, yaya dostu ulaşımın sağlanması için yol ve kaldırım genişliklerine dair standartlara ihtiyaç bulunmaktadır. Ayrıca, çevreyi kirleten, kent içinde kalmış ticaret ve sanayilerin bu tür konut alanlarında daha fazla olması nedeniyle, bunların önüne geçilmesi yönünde çözümler geliştirilmelidir.

Kent merkezinde yapılaşma baskısı altındaki tarihi alanlar: Bu tür alanlarda, eskiyen konutların yeniden inşası ve benzeri dönüşüm müdahalelerinde, alandaki tipolojinin, özellikle tarihi kimlik ve karakter özelliklerinin kaybedilmemesi esas olmalıdır. Parsel, ada hatta komşuluk düzeyinde tanımlanması gereken yapılaşma standartları, kentlinin ihtiyacı olan açı yeşil alanları, yaya dostu ulaşımı, araç park yerlerini ve yol genişliklerini göz önüne alacak şekilde düzenlenmelidir.

Sonuç olarak, kentsel alanların fiziksel kalitesini değerlendirmek için, imar mevzuatında yer alan açık-yeşil alanların kişi başına düşen miktarlarının belirlenmesi gibi standartların yeterli olmadığı anlaşılmaktadır. Yapı adası ve komşuluk düzeylerinde belirlenecek SKB ilkelerini esas alan asgari ölçütler geliştirildiği takdirde, yeni gelişme konut alanlarının daha sağlıklı ve yaşanabilir olması sağlanabilir. Benzer biçimde, mevcut dokudaki kusurların tespitinde, kentsel dönüşüm türleri ve önceliklerinin belirlenmesinde kullanılmak üzere, SKB ölçütlerini kullanan performans programları geliştirilmelidir. Bu çalışma kapsamında yer alan ölçütler kısıtlı olmasına rağmen, gelecekteki araştırmalarda dâhil edilecek diğer SKB ilkeleriyle birlikte, ülkemize özgü yapılacak çalışma ve incelemelere yol göstereceği düşünülmektedir.

\section{Teşekkür}

Bursa Teknik Üniversitesi'ne 191N026 No'lu "Kentsel Yaşam Kalitesinin Fiziksel Çevre ve Toplum Özellikleri Açısından İncelenmesi: Bursa Yıldırım İlçesi Konut Alanları Örneği" isimli Bilimsel Araştırma Projesi kapsamında sağladığı destek için ve İdealKent Dergisi editörü ve hakemlerine değerli yorumları ve katkıları için teşekkür ederiz. 


\section{$\underline{\text { Extended Abstract }}$}

\section{Evaluation of Sustainable Urban Form Quality: The Case of Residential Areas in Yıldırım District of Bursa}

\author{
Arzu Taylan Susan \\ ORCID: 0000-0001-5718-8794
}

Zeynep Erdoğan

ORCID: 0000-0002-4881-3524
*

\author{
Melek Gökmeydan \\ ORCID: 0000-0001-5113-5405 \\ Arda Tuncer \\ ORCID: 0000-0002-4846-0263
}

The concept of quality of life (QoL) enables development of social and economic policies, when studies on urban quality of life (U-QoL) have special contribution into city planning. Recently, sustainable development policies have led to reconnect U-QoL and city planning in the framework of sustainability. However, as traditional planning is usually involved with the improvement of U-QoL in the physical environment, the place production practice requires integrating the physical characteristics of urban tissue into sustainability. This is what the emerging sustainable urbanization approaches such as smart city and new urbanism implement by developing new techniques involved with urban form in neighborhood scale. Along with these, neighborhood certification programs such as LEED-ND implement performance-based quality assessment methods by employing morphological methods to determine characteristics of sustainable urban form (SUF).

Depending on development legislation and its regulations, the planning process in Turkey also gives significance to quantitatively measurable and controllable standards during the place production practice in urban scale. In city development plans, amenities such as open green spaces are limited to per capita area assessments, while qualitative issues like accessibility to services and green areas remain usually overlooked without any written regulation and guide but depending on city planners' ability and skills as well as local authorities' willingness. Hence, developing qualitative measures as a part of legislation and regulations is a particular need to improve U-QoL 
through spatial planning practice in Turkey in order to improve physical quality in urban environments. In this context, the aim of the article is to evaluate spatial quality indicators, which provide measuring physical dimension of U-QoL in residential environments that are peculiar to Turkey; therefore, to contribute into development of legislative regulations that aim generation of healthier and livable urban areas.

Then, the study employed physical QoL indicators obtained from the sustainable urbanization approaches, which intend to improve urban QoL such as smart growth, new urbanism, ecological and compact cities. The study has also utilized the indicators used in the certificate programs, particularly in the LEED-ND program that originate from USA, which certifies the neighborhoods according to the characteristics of their physical environment through U-QOL indicators involved with SUF and ecological principles. After selecting SUF indicators- i.e. compactness, density, accessibility, permeability, open-green places, mixed-land use and diversity-the study discussed them through urban design literature and compared their existence and limitations with Turkish development legislation. Then U-QOL indicators based on SUF are developed in terms of transforming the unmeasurable qualitative characteristics into measurable quantitative indicators.

Therefore, the study evaluated their performance in the selected houseenvirons at the building-block scale. Investigating the morphological characteristics in Ylldırım districts of Bursa based on the historical development, legislative period and main attributes of buildings and parcels, we obtained morphologically similar six regions. The selected areas are: (1) traditional housing areas at the inner city (Yeşil neighborhood), (2) shared ownership houses at the inner periphery (Beyazid neighborhood), (3) shared ownership houses at the outer periphery, i.e. near to first industrial areas of the city (Arabayatağı neighborhood), (4) shared ownership at the outer-periphery of the city (Şirinevler neighborhood), (5) housing areas developed through legal initiatives like housing cooperatives (Siteler neighborhood) and (6) housing areas that developed recently as gated-communities (Millet neighborhood). From each morphological region. Then, we selected one neighborhood from each morphological region and one building block from each neighborhood to compare their performance for the developed U-QoL indicators based on SUF.

Based on findings, the selected areas have usually met the density and mixed-used measures, whereas walkability and open-green areas were 
scarce. In the traditional neighborhood, i.e. Yeşil, the four-five story apartment blocks, which replace the low-story houses with gardens, increase the density not proportionately due to causing loss of gardens and open-green areas of traditional housing typologies. Although buildings define street facades, narrow streets do not promote walkability, when streets were inaccessible due to street parking of automobiles. Siteler district of cooperative houses has performed almost all U-QoL-SUF measures at highest proportion. Particularly, location of buildings provides urban patterns with semi-public open green areas, with higher accessibility and permeability. Millet district of semi-gated communities has denser population that provide mixed-land-use. Despite, the permeability of building blocks was lower due to limited access into the housing areas. Moreover, in spite of lack of public green areas, common public areas within housing areas usually serve for car parking instead of green areas, while high ratio of mixed-land use cause car parking needs on the streets. The detached houses in inner periphery area, i.e. Beyazid neighborhood, houses produced through illegal processes lack the balance of density and open-green areas. In Arabayatağı neighborhood, on the other hand, the decreased walkability due to lack of pedestrian ways accompanies to lack of permeability and green areas as well as mixed-land use but small and polluting industries emerged within housing areas. Finally, although the outer periphery housing areas in Şirinevler, has similar building-block characteristics with unbalanced density and open areas, the walkability and publicly used open and green areas were in higher proportion.

In conclusion, the produced housing environs in Turkish urbanization process seems to be insufficient, particularly in socially produced areas. Most problems arise from balancing density and open-green areas, which leads inaccessibility and insecure pedestrian walkability, less green areas and car parking problems. Determination of standards for qualitative characteristics of urban form is necessary for more sustainable and higher quality urban environments. These standards can differ according to the typological characteristics and should be beyond the parcel scale, but at least at the building block scale. They can include the minimum and maximum measures as the length of urban blocks, their open areas inside and between buildings as well as open green areas in walkable distances, permeability of building blocks, balancing car parking and pedestrian ways. 


\section{Kaynakça/References}

Alexander, C., Ishikawa, S. ve Silverstein, M. (Jacobson, M., Fiksdahl-King, I. ve Angel, S. ile birlikte) (1977). A pattern language: towns, buildings, construction, New York: Oxford University Press.

Bache, I. ve Scott, K. (2017). Politics and wellbeing. (CWIPP Working Paper No.10), Center for Wellbeing in Public Policy, The University of Sheffield.

Bölen, F., Türkoğlu, H., Ergun, N., Yirmibeşoğlu, F., Kundak, S., Terzi, F. ve Kaya, S. (2006). İstanbul'da konut alanlarında fiziksel çevre kalitesi analizi. IMP Konut ve Yaşam Kalitesi Grubu Raporu, İstanbul: İstanbul Büyükşehir Belediyesi.

BYB (2020). Kent bilgi sistemi verisi. Bursa Yıldırım Belediyesi

Camagni, R., Capello, R. ve Nijkamp, P. (1998). Towards sustainable city policy: an economy-environment technology nexus. Ecological economics, 24(1), 103-118.

Carmona, M., Heath, T., Oc, T. ve Tiesdall, S. (2003). Public places urban spaces the dimensions of urban design. Oxford: Architectural Press.

Chen, S., Cerin, E., Stimson, R., ve Lai, P. C. (2016). An objective measure to assessing urban quality of life based on land use characteristics. Procedia Environmental Sciences, 36(Supplement C), 50-53. https://doi.org/10.1016/j.proenv.2016.09.009

Cheng, Z., Smyth, R. ve Wang, H. (2013). Housing and subjective wellbeing in urban China. (Department of Economics Discussion Paper, no. 39-13), Monash University.

Chhetri, P., Han, J. H., Chandra, S., ve Corcoran, J. (2013). Mapping urban residential density patterns: compact city model in Melbourne, Australia. City, Culture and Society, 4(2), 77-85. doi:10.1016/j.ccs.2013.03.001

Chiu, R. (2003). Social sustainability, sustainable development and housing development, Housing and social change: East-west perspectives (Vol. 221): Routledge

Diener, E. ve E. Suh (1997). Measuring quality of life: economic, social, and subjective indicators, Social Indicators Research 40(1-2): 189-216.

Elariane, S. A. (2012). Neighbourhood urban quality of life: guidelines for urban planning and development of new assessment tool. (Doktora tezi). Faculty of Engineering, Cairo University. Giza, Egypt. Erişim adresi: http://www.cpas-egypt.com/

El Din, H. S., Shalaby, A., Farouh, H. E. ve Elariane, S. A. (2013). Principles of urban quality of life for a neighborhood. Hbrc Journal, 9(1), 86-92.

Ersoy, M., (2007). Kentsel planlama kuramları. Ankara: İmge Kitapevi.

Ertürk, H. ve Karakurt-Tosun, E. (2009). Küreselleşme sürecinde kentlerde mekânsal, sosyal ve kültürel değişim: Bursa örneği. Uludă̆ Üniversitesi Fen-Edebiyat Fakültesi Sosyal Bilimler Dergisi, 10 (16), 37-53.

Farr, D. (2008). Sustainable urbanism, urban design with nature. Farr Associates. New Jersey: John Wiley \& Sons, Inc.

Fleming, D. (1998). The Space of argumentation: urban design, civic discourse, and the dream of the good city, Argumentation, 12: 147-166.

Google (2021, 1 Kasım). [Yıldırım, Bursa için google maps uydu görüntüsü]. Erişim adresi: https://goo.gl/maps/XsiVNpzZU7SgE6c77 
Gouda, A. A., ve Masoumi, H. E. (2018). Compactness, connectivity, and walking accessibility on the neighborhood level according to sustainability certifications: improvement or downgrade? A case study of Cairo, Egypt. Journal of Geographical Systems, 20(4), 413-449. doi:10.1007/s10109-018-0272-7

Handy, S. (1996). Methodologies for exploring the link between urban form and travel behavior. Transportation Research Part D: Transport and Environment, 1(2), 151-165.

İlkme, M. (2009, 27 Aralık). Bursa kent raporu. TMMOB Şehir Plancıları Odası Bursa Şubesi.

Erişim adresi: http://www.spo.org.tr/genel/bizden_detay.php?kod=840\&tipi=2\&sube=3

Jabareen, Y. (2013). Planning the resilient city: concepts and strategies for coping with climate change and environmental risk. Cities, 31, 220-229.

Jabareen, Y. R. (2006). Sustainable urban forms: their typologies, models, and concepts. Journal of Planning Education and Research, 26 (1), 38-52.

Jacobs, J. (1961). The death and life of great American cities. New York: Vintage Books.

Jones, C., Jenks, M. ve Bramley, G. (2010). Complementarities and contradictions, M. Jenks ve C. Jones (Ed.), Dimensions of the sustainable city (s. 239-256) içinde, Dordrecht, Heidelberg, Londra, New York: Springer.

Kaya, H. E., ve Taylan Susan, A. (2020). Sürdürülebilir bir kentleşme yaklaşımı olarak, ekolojik planlama ve eko-kentler. İdealKent Dergisi, 11(30).

Keleş, R. (2006). Kentleşme politikası, Ankara: İmge Yayınevi.

Kropf, K. (2017). The handbook of urban morphology. New Jersey, NJ: Wiley.

Larkham, P. J., ve Jones, A. N. (Ed.). (1991). A glossary of urban form. Historical Geography Monograph, no. 26, Urban Morphology Research Group, School of Geography, University of Birmingham.

LEED v4 (2018, 3 Eylül). LEED v4 for neighborhood development - current version, Erişim adresi: https://www.usgbc.org/resources/leed-v4-neighborhooddevelopment-current-version

Lynch, K. (1981). A theory of good city form. Cambridge: MIT Press.

Madanipour, A. (2003). Public and private spaces of the city. London: Routledge.

Marans, R. W. (2015). Quality of urban life \& environmental sustainability studies: future linkage opportunities. Habitat International, 45: 47-52. doi:10.1016/j.habitatint.2014.06.019

Marans, R. W. (2003). Understanding environmental quality through quality of life studies: the 2001 DAS and its use of subjective and objective indicators. Landscape and Urban Planning, 65(1), 73-83.

Maryanti, M., Khadijah, H., Uzair, A. M., ve Ghazali, M. (2017). The urban green space provision using the standards approach: issues and challenges of its implementation in Malaysia. WIT Transactions on Ecology and the Environment, 210, 369-379. 
McCrea, R., Stimson, R., ve Marans, R. W. (2011). The evolution of integrative approaches to the analysis of quality of urban life. R.W. Marans ve R. Stimson (Ed.), Investigating quality of urban life (s. 77-104) içinde, Dordrecht: Springer.

Moughtin, C. (2003). Urban design street and square. Great Britain: Elsevier Science.

Nedovic-Budic, Z., Knaap, G. J., Shahumyan, H., Williams, B., ve Slaev, A. (2016). Measuring urban form at community scale: case study of Dublin, Ireland. Cities, 55, 148-164.

Newman, P. W. (1999). Sustainability and cities: extending the metabolism model. Landscape and Urban Planning, 44(4), 219-226.

Oikonomou, M. (2015). The urban block as a potential for sustainable urban design. The Sustainable City X, 194, 69.

Oktay, D. (2001). Kentlerimiz, yaşam kalitesi ve sürdürülebilirlik. Mimarlık Dergisi, 302: 45-49.

Pacione, M. (1982). The use of objective and subjective measures of life quality in human geography. Progress in Geography, 6(4), 495-514.

Pakzad, E., ve Salari, N. (2018). Measuring sustainability of urban blocks: the case of Dowlatabad, Kermanshah city. Cities, 75, 90-100.

Porta, S., ve Renne, J. L. (2005). Linking urban design to sustainability: formal indicators of social urban sustainability field research in Perth, Western Australia. URBAN DESIGN International, 10(1), 51-64.

Rezvani Kakhki, S., Rahnama, M. R., ve Ajza Shokouhi, M. (2018). Urban form analysis based on smart growth characteristics at neighborhoods of 9th district in Mashhad Municipality. Modern Applied Science, 12.

Shach-Pinsly, D., ve Capeluto, I. G. (2020). From form-based to performance-based codes. Sustainability, 12(14), 5657, doi:10.3390/su12145657

Sınmaz, S. (2013). Yeni gelişen planlama yaklaşımları çerçevesinde akıllı yerleşme kavramı ve temel ilkeleri. Megaron, 8(2), 76.

TC-ÇŞB. (2017). Kentsel mekânsal standartlarm geliştirilmesi. Ankara: T.C. Çevre ve Şehircilik Bakanlığı.

Tekeli, İ., Güler, Ç., Vaizoğlu, S., Algan, N. ve Kaya Dündar, A (2010). Yaşam kalitesi göstergeleri: Türkiye için bir veri sistemi önerisi. Ankara, Türkiye Bilimler Akademisi.

TÜİK (2020a). 1990 Genel nüfus sayımı. Türkiye İstatistik Kurumu.

TÜİK (2020b). 2000 Genel nüfus sayımı. Türkiye İstatistik Kurumu.

Türkoğlu, H. (2015). Sustainable development and quality of urban life. Procedia - Social and Behavioral Sciences, 202 (Supplement C), 10-14. https://doi.org/10.1016/j.sbspro.2015.08.203

Türksever, A. N. E. (2000). Türkiye'de büyük şehir alanlarında yaşam kalitesinin değerlendirilmesine yönelik bir yöntem denemesi. Yayımlanmamış doktora tezi, Fen Bilimleri Enstitüsü, İstanbul Teknik Üniversitesi.

Van Kamp, I., Leidelmeijer, K., Marsman, G., ve De Hollander, A. (2003). Urban environmental quality and human well-being: towards a conceptual framework 
and demarcation of concepts; a literature study. Landscape and Urban Planning, 65 (1), 5-18.

Veenhoven, R. (2000). The four qualities of life. Journal of Happiness Studies, 1(1), 1-39. Yazarlar (2020). Yazarların kendi fotoğraf arşivi, Alan araştırması, Yıldırım, Bursa.

Yıldız, S., Yılmaz, M., Kıvrak, S. ve Gültekin, A.B. (2016). Neighborhood sustainability assessment tools and a comparative analysis of five different assessment tools, Journal of Planning, 26(2):93-100, doi: 10.14744/planlama.2016.05914

Walters, D. R. (2007). Designing community: charrettes, master plans and form-based codes. UK \& USA: Elsevier.

Wheeler, S. M. (2003). The evolution of urban form in Portland and Toronto: implications for sustainability planning. Local Environment, 8(3), 317-336. doi:10.1080/13549830306656

Zuniga-Teran, A. A., Orr, B. J., Gimblett, R. H., Chalfoun, N. V., Going, S. B., Guertin, D. P., ve Marsh, S. E. (2016). Designing healthy communities: a walkability analysis of LEED-ND. Frontiers of Architectural Research, 5(4), 433-452. 